\title{
Mouse models of altered protein kinase A signaling
}

\author{
Lawrence S Kirschner, Zhirong Yin, Georgette N Jones and Emilia Mahoney
}

Division of Endocrinology, Diabetes and Metabolism, Department of Internal Medicine, and Department of Molecular Virology, Immunology and Medical Genetics, The Ohio State University, 420 West 12th Avenue, TMRF 544, Columbus, Ohio 43210, USA

(Correspondence should be addressed to L S Kirschner; Email: lawrence.kirschner@osumc.edu)

\begin{abstract}
Protein kinase $A(P K A)$ is an evolutionarily conserved protein which has been studied in model organisms from yeast to man. Although the CAMP-PKA signaling system was the first mammalian second messenger system to be characterized, many aspects of this pathway are still not well understood. Owing to findings over the past decade implicating PKA signaling in endocrine (and other) tumorigenesis, there has been renewed interest in understanding the role of this pathway in physiology, particularly as it pertains to the endocrine system. Because of the availability of genetic tools, mouse modeling has become the pre-eminent system for studying the physiological role of specific genes and gene families as a means to understanding their relationship to human diseases. In this review, we will summarize the current data regarding mouse models that have targeted the PKA signaling system. These data have led to a better understanding of both the complexity and the subtlety of PKA signaling, and point the way for future studies, which may help to modulate this pathway for therapeutic effect.
\end{abstract}

Endocrine-Related Cancer (2009) 16 773-793

\section{Introduction}

\section{PKA as a pre-eminent second messenger system}

Protein kinase A (PKA) or the cAMP-dependent protein kinase is a serine-threonine kinase that was characterized initially as mediating the effects of elevated cAMP levels, which arose as a result of stimulation of cell membrane by epinephrine (Sutherland \& Rall 1958, Walsh et al. 1968). These observations formed the basis for understanding hormonal signaling, and provided the basis for two Nobel prize awards in Medicine, to Sutherland (in 1971) and subsequently to Gilman \& Rodbell (in 1994). Studies of PKA have formed the basis of signal transduction mediated through protein phosphorylation, and the characterization of this enzyme can be thought to lie at the 'root' of recent analysis of all human protein kinases (Manning et al. 2002).

In canonical PKA signaling, extracellular hormones bind to G-protein coupled receptors, a large family of seven transmembrane domain proteins involved in many forms of intercellular communication. After liganding of the receptor, a conformational change is triggered to activate the associated heterotrimeric G-protein. For PKA signaling, these receptors couple to the stimulatory G-protein, Gs. Subsequent dissociation of the Gs complex allows Gs $\alpha$ to associate with membrane bound adenylyl cyclases (ACs), which catalyze the conversion of ATP to cAMP. cAMP binds to PKA, dissociating the inactive holoenzyme and inducing phosphorylation of downstream targets (Fig. 1).

Through early characterization, it was determined that the PKA holoenzyme is comprised of four subunits, two of which are catalytically active (PKAC subunits), and two of each serve to regulate enzyme activity (PKAR subunits). When bound together, the heterotetrameric enzyme is inactive. However, when cAMP levels within the cell rise in response to membrane signaling, cAMP binds cooperatively to paired binding pockets on each of the regulatory subunits, causing release of free, catalytically active, PKAC monomers. Initial studies revealed that manipulation of PKA activity produced changes in the activity of protein substrates (e.g. phosphorylase kinase (Walsh et al. 1968)), but also changes in gene transcription, a function mapped to PKA's ability to 


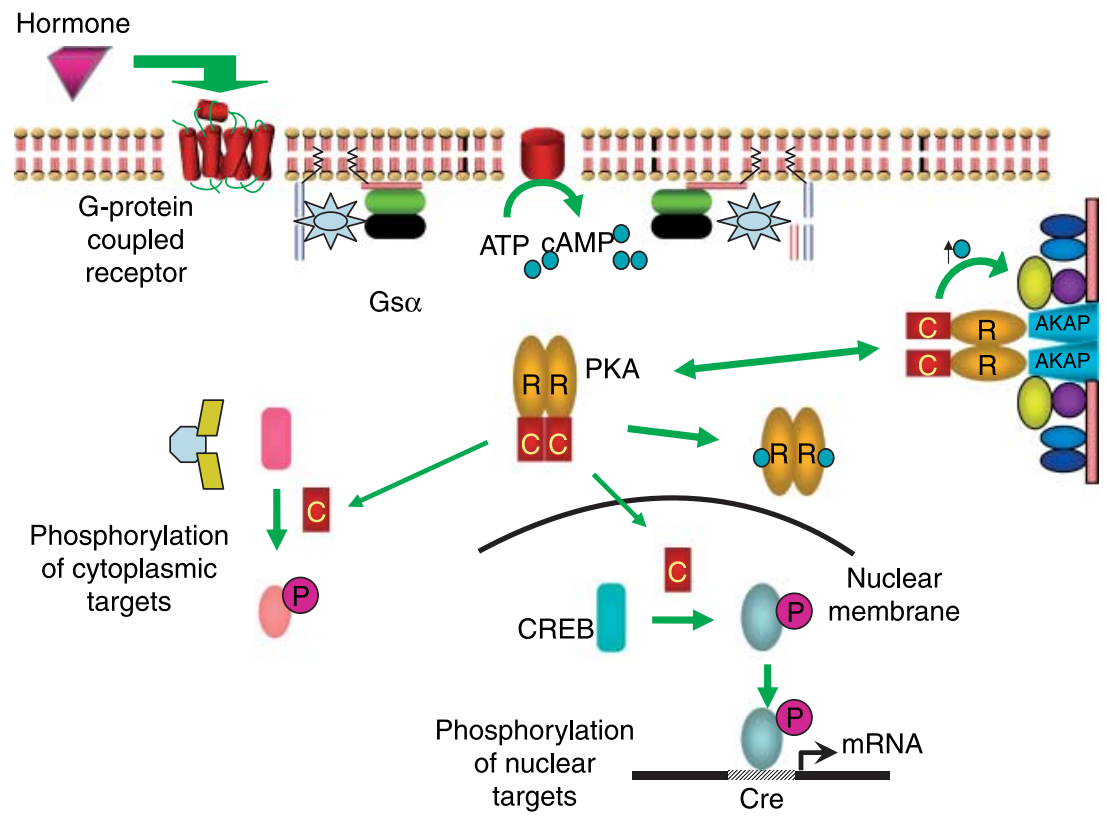

Figure 1 General overview of protein kinase A signaling. This diagram depicts the canonical PKA signaling pathway. In this model, signaling is initiated by a hormone binding to a transmembrane receptor, activating Gs $\alpha$, leading to the production of cAMP (blue circles) by adenylyl cylase. cAMP binds to the PKA heterotetramer, releasing PKAR subunit dimers and free PKAC subunits (red squares). The catalytic subunits phosphorylate both cytoplasmic and nuclear targets (for e.g. CREB), leading to the downstream effects of this intercellular signaling mechanism. At right is shown a PKA-AKAP multiprotein complex which can lead to the phosphorylation of substrates in a highly localized fashion in response to cAMP elevation.

phosphorylate the transcription factor cAMP response element binding protein (CREB; Montminy 1997, Mayr \& Montminy 2001, Rosenberg et al. 2002), which functionally binds throughout the DNA transcriptome (Conkright et al. 2003). A myriad of studies over the past 40 years have identified hundreds (if not thousands) of PKA substrates, both in the nucleus and in the cytoplasm (Budovskaya et al. 2005, Huang et al. 2007, Neuberger et al. 2007, Gao et al. 2008). Like other post-translational protein modifications, PKAmediated phosphorylation can affect any aspect of target protein function, including activity, localization, and stability (Huang et al. 2000, Mason et al. 2002, Higuchi et al. 2003, Qiao et al. 2003, Hoang et al. 2004, Hino et al. 2005, Rolli-Derkinderen et al. 2005), such that PKA exerts complex effects on most biologic systems. For this reason, pharmacologic or genetic manipulation in tissue culture cells may produce only a limited understanding of the pleomorphic role of PKA signaling.

To better appreciate the complexity of PKA signaling, significant work has been invested in generating mouse models with genetic manipulation of the PKA system. Although these systems are all to some extent artificial, they allow specific investigation of various aspects of PKA signaling, with a focus on altered physiology in an intact organism. Thus, these mouse models provide perhaps the best way in which to appreciate how modulation of this system may produce physiological changes, and might profitably be modulated for therapeutic purposes. For the bulk of the review, we will focus on genetic manipulation of the PKA subunits themselves, although other genetic models that affect PKA signaling will also be addressed.

\section{Components of the PKA signaling system}

\section{Biochemistry of the PKA system}

PKA is evolutionarily conserved, such that analysis of PKA function has been carried out in organisms ranging from yeast (Tamaki 2007, Thevelein et al. 2008), through Caenorhabditis elegans and Drosophila (Noveen et al. 1996, The et al. 1997, Vanfleteren \& De Vreese 1997, Angelo \& Rubin 1998), to mammals (Skalhegg \& Tasken 2000). Because the review of each of these model systems is beyond the scope of this review, we will focus on the human PKA system, and how this relates to the genetically tractable mouse system.

Biochemical studies have identified two distinct isoforms of PKA, which exhibit different physical and biochemical properties. Type 1 PKA is eluted off anion exchange chromatography columns at a relatively low 
salt concentration, and exhibits binding affinity for cAMP in the 40-50 nM range (Woodford et al. 1989). By contrast, type 2 PKA requires higher salt concentrations to recover the enzyme, and exhibits a slightly lower affinity for cAMP, with affinities in the 50-200 nM range (Robinson-Steiner et al. 1984, Rannels et al. 1985). Because of both kinetic and affinity parameters of cAMP binding, it is thought that the bulk of the cytosolic PKA activity derives from dissociation of type 1 PKA complexes. However, this does not exclude the likelihood that type 2 PKA plays an important signaling roles owing to very high localized concentrations of cAMP generated at the site of large multiprotein signaling complexes nucleated by A-kinase anchoring proteins (AKAPs; Feliciello et al. 2001, Diviani et al. 2006).

PKA catalytic subunits. At the genetic level, humans have three PKAC subunit genes, designated as PRKARCA, PRKARCB, and PRKARCG. The three genes produce three corresponding $-\alpha,-\beta$, and $-\gamma$ isoforms of the catalytic subunits. Functional studies have not identified significant functional differences among the three isoforms, although there is tissuespecificity of expression. By contrast, there are only two isoforms of PKA catalytic subunits found in mice $-\mathrm{C} \alpha$ and C $\beta$ (encoded by Prkaca and Prkacb). Of these two isoforms, there also exist splice variants that have similarities to those found in humans. The $\mathrm{C} \alpha$ subunit consists of two splice variants defined as $\mathrm{C} \alpha 1$ and $\mathrm{C} \alpha 2$, also referred to as $\mathrm{C} \alpha$-s (Uhler et al. 1986a,b, San Agustin \& Witman 2001). Although the $\mathrm{C} \alpha 1$ isoform is expressed ubiquitously in mice, the expression of $\mathrm{C} \alpha 2$ is restricted to male germ cells, and it was shown that $\mathrm{C} \alpha 2$ is the only catalytic subunit of PKA expressed in mature sperm (Desseyn et al. 2000). C $\beta$, on the other hand, has three splice variants - C $\beta 1, C \beta 2$, and $C \beta 3$ (Uhler et al. 1986a,b, Guthrie et al. 1997). C $\beta 1$ is ubiquitously expressed, albeit at lower levels than $\mathrm{C} \alpha 1$, however, $C \beta 2$ and $C \beta 3$ expressions are limited to the brain. More specifically, $C \beta 2$ expression is highest in the limbic regions of the brain, whereas $C \beta 3$ is more diffusely expressed throughout various brain regions at low levels (Guthrie et al. 1997). While the C $\beta$ isoforms comprise the major PKAC component in the brain, $\mathrm{C} \alpha 1$ is considered to be the predominant source of PKA catalytic activity in non-neuronal tissues (Uhler et al. 1986a,b).

Both catalytic isoforms exhibit alternative splicing events at the first exon, resulting in amino-terminal differences between transcript variants. Interestingly, the $\mathrm{C} \alpha 1$ and $C \beta 1$ isoforms exhibit around 91\% homology, and they are both myristoylated at the N-terminus
(Uhler et al. 1986a,b, Yonemoto et al. 1993, Guthrie et al. 1997, Desseyn et al. 2000). Conversely, C $\alpha 2$, $\mathrm{C} \beta 2$, and $\mathrm{C} \beta 3$ are all non-myristoylated due to splicing of alternative first exons that provide novel translation start sites and result in truncated amino termini (Guthrie et al. 1997, Desseyn et al. 2000). It is thought that $N$-myristoylation of $\mathrm{C} \alpha 1$ and $\mathrm{C} \beta 1$ is not important for membrane tethering, as is commonly assumed with this type of co-translational modification; rather it is important for protein structural integrity and thermal resistance (Yonemoto et al. 1993). However, the lack of myristoylation in the truncated isoforms suggests that this modification is not essential for protein stability.

PKA regulatory subunits. For the regulatory subunits, there are four genes, two encoding type 1 subunits and two encoding type 2 subunits. The type 1 subunit genes, PRKARIA and PRKARIB, exhibit differential expression patterns, with the former expressed ubiquitously, and the latter limited to neural and adipose tissue. The type 2 subunit genes, PRKAR2A and $P R K A R 2 B$, exhibit similar differential expression, although the levels of these two transcripts in most tissues appear generally to be lower than their type 1 counterparts. The RII $\beta$ subunit is also selectively expressed, being highest in the central nervous system (CNS), neuroendocrine tissues, Sertoli cells, ovarian granulosa cells, and lung (Skalhegg \& Tasken 2000). In mice, the PKA regulatory system uses the same genetic complement, with the corresponding mouse genes known as Prkarla, $-r l b,-r 2 a$, and $-r 2 b$. The expression patterns in mice have been better studied than in human subjects, with similar findings to those described above. For the PRKARlA/Prkarla genes, there is alternative splicing at the $5^{\prime}$ end of the gene. This allows the usage of multiple promoters; however, given the fact that the initiation ATG is located in the second exon, the encoded proteins are identical (Solberg et al. 1997, Barradeau et al. 2000).

PKA inhibitors. In addition to PKAC and PKAR subunits, PKA activity is also modulated by the PKA inhibitor (PKI) proteins, which are small, heat stable proteins that are capable of binding and inhibiting PKAC directly. In humans and mice, there are three PKA genes (PKIA, PKIB, and PKIG). The three PKI isoforms appear to exhibit similar biochemical function but different tissue-specific patterns. PKI $\alpha$ is expressed primarily in muscle, whereas PKI $\beta$ is expressed at very high levels in the testes. The third gene family member, PKI $\gamma$, exhibits ubiquitous expression, but seems to be present at lower levels than the first two. 


\section{A-kinase anchoring proteins}

Early biochemical characterization of the PKA signaling system noted that PKA activity could be partitioned into the cytosolic (soluble) and membrane bound (particulate) fractions that exhibited differential enzymatic behavior (Corbin et al. 1977). The search for the molecular basis of this observation led to the identification of AKAPs, a family of proteins that bind to PKA and enable its subcellular distribution. This topic has been extensively reviewed (Michel \& Scott 2002, Ruehr et al. 2004, Dell'Acqua et al. 2006, Beene \& Scott 2007, Jarnaess \& Tasken 2007, Dodge-Kafka et al. 2008) and will not be covered in the depth; however, a few points are worth highlighting.

Although there are only 15 AKAP genes in humans, most of the genes exhibit alternative splicing, so that $>50$ distinct proteins have been described. In addition to these genes, proteins with other functions in the cell have been shown to serve as AKAPs, although they were initially characterized for other activities (Jarnaess \& Tasken 2007). Examples of this latter class of AKAP include cytoskeletal linking proteins of the FERM family, including both Ezrin (Sun et al. 2000) and Merlin (NF2; Gronholm et al. 2003), as well as the microtubule-associated protein 2 (MAP2; Harada et al. 2002). For most of the AKAPs, the binding affinity for type 2 PKA is significantly higher than for type 1, although some AKAPs (particularly AKAP1/D-AKAP1 and AKAP10/D-AKAP2) appear to be able to bind both type 1 and type 2 with reasonable affinity.

PKA-AKAP complexes are multiprotein structures that contain the components to provide exquisite signal feedback control. In addition to binding PKA, most AKAPs also bind phosphodiesterases of the PDE4 family, which tightly regulate cAMP levels as part of a complex feedback loop. Perhaps the best characterized is an AKAP6 (mAKAP)-containing complex, which not only contains PKA and PDE4D3, but the cAMPresponsive protein Epac, Rap1, and ERK5, all of which co-exist within overlapping feedback loops (Dodge-Kafka et al. 2005). Other AKAP complexes contain PP1- or PP2-type phosphatases, for regulation of protein phosphorylation state (Michel \& Scott 2002, Dell'Acqua et al. 2006, McConnachie et al. 2006). In addition to the signaling components, PKA-AKAP complexes are typically localized to PKA-regulated targets, including membrane channels and receptors. As PKA-mediated phosphorylation of these target proteins affects their function within the cell and thence cell behavior, it is inherently obvious why so much cellular effort goes into the exquisite spatiotemporal regulation of PKA activity at these sites.

\section{Relation to human disease (and endocrine cancer)}

Although PKA signaling has been studied in cells for many years, recent interest in this field has been kindled by the observations that abnormalities of the PKA signaling pathway are associated with human disease. This paradigm was initially discovered in association with the McCune-Albright syndrome (MAS), an endocrine hyperplasia/hyperfunction syndrome caused by activating mutations in the GNAS1 gene, which stimulates AC and drives PKA activity in cells where the mutant protein is expressed (Weinstein et al. 1991, Shenker et al. 1994).

Because MAS can be associated with pituitary tumors and hyperfunctioning thyroid nodules (among other manifestations), these tumor types were also evaluated for mutations in the GNAS1 gene. Mutations in this gene are found in $\sim 33 \%$ of GH-secreting pituitary tumors (Vallar et al. 1987, Barlier et al. 1998), but are uncommon in thyroid tumors, although there have been case reports of these mutations in congenital autonomous goiters (Weinstein et al. 2001, Palos-Paz et al. 2008). By contrast, activating mutations of the TSH receptor, which signals through GNAS1, have been described both in nodules and in congenital cases (Parma et al. 1993, 1997, Russo et al. 1995, Fuhrer et al. 1997a,b, Cetani et al. 1999, Postiglione et al. 2002, Palos-Paz et al. 2008).

Perhaps the most striking demonstration of the association of PKA abnormalities with human disease was the finding within the last decade that the inherited multiple endocrine neoplasia syndrome Carney Complex (CNC) is due to inactivating mutations in the PRKARIA gene (Kirschner et al. 2000a,b). Although CNC is genetically heterogeneous, mutations of PRKARIA appear to account for $60-75 \%$ of CNC patients, either in the sporadic or familial setting (Bertherat 2006). Mutation of this gene leads to enhanced PKA activity and tumorigenesis (Kirschner et al. 2000a,b). Subsequent to this observation, it has been demonstrated that the same gene can be lost from sporadic adrenocortical tumors (Bertherat et al. 2003) or from advanced thyroid cancers (Sandrini et al. 2002a,b). These latter tumors exhibit loss of heterozygosity $(\mathrm{LOH})$ at the PRKARIA locus in about one-third of the advanced tumors. Although genetic changes in this gene have not been observed in pituitary tumors (Kaltsas et al. 2002, Sandrini et al. 2002a,b, Yamasaki et al. 2003), analysis of protein expression has suggested that it may be down-regulated by epigenetic means specifically in GH-producing tumors (Lania et al. 2004). 
Most recently, mutations in the PDE11 and PDE8 genes, which are involved in the degradation of cAMP, have been detected in adrenocortical neoplasms (Horvath et al. 2006, 2008). These findings confirm the strong biological link between PKA activation and hyperproliferation/tumorigenesis.

\section{Understanding the function of PKA subunits by conventional gene knockout models}

\section{PKA catalytic subunit knockout mouse models}

Skalhegg et al. (2002) described a mouse in which both the $C \alpha 1$ and $C \alpha 2$ subunits were effectively knocked out by replacing exons $6-8$ with a neomycin resistance cassette. This targeted deletion of the $\mathrm{C} \alpha$ subunits led to perinatal lethality or delayed growth in mice. Because $C \alpha 1$ is not only ubiquitously expressed, but also predominantly activated in non-neuronal tissues, the effect on homozygous null $\left(\right.$ Prkaca $\left.^{-/}\right)$animals was widespread. Additionally, due to the specificity of $\mathrm{C} \alpha 2$ to the testis, there were also dramatic defects seen in sperm function in these animals.

The most notable defect seen in Prkaca $^{-/-}$mice was their delayed growth. Indeed, most mutant animals died perinatally; however, $\sim 27 \%$ survived to adulthood. Of this small percentage of mice, there was a marked decrease in overall body size at three months of age, such that mutant mice weighed only about $65 \%$ as much as their wild-type (WT) littermates (Skalhegg et al. 2002). More recently, it has been shown that the epithelial growth factor receptor protein levels are significantly decreased in Prkaca $^{-/-}$mice, which highlight a possible mechanism by which loss of PKA activation potential results in an impaired ability for cells to convey growth signals (Oksvold et al. 2008).

In the germ cells of male Prkaca ${ }^{-/-}$mice, loss of the catalytic subunits translated to normal testis histology, and normal spermatogenesis as expected, since PKA activity is normally minimal in these cells (Skalhegg et al. 2002). However, after maturation, Prkaca $^{-1-}$ sperm displayed significant malformations in head shape and forward velocity as compared with sperm from normal littermates. These results are interesting, given that the opposite effect is seen in Prkarla heterozygotes, which exhibit fertility problems associated with deficient sperm development and overall reduced sperm count (Burton et al. 2006). Taken together, these data represent the fine balancing act of activation and suppression of PKA in order that the appropriate development and function of adult tissues can be achieved.
In contrast to Prkaca $^{-/-}$mice, the conventional knockout (KO) mice for $\mathrm{C} \beta 1\left(\operatorname{Prkacb}[\beta 1]^{-/-}\right)$are viable, fertile, and phenotypically indistinguishable from their WT littermates (Qi et al. 1996). Interestingly, the only differences observed between mice lacking $C \beta 1$ and normal mice were observed in the hippocampus. Although $C \beta 1$ null hippocampal slices could be stimulated acutely, they were unable to potentiate electrostimuli along the Schaffer CollateralCA1 pathway to the same extent as normal hippocampal slices in vitro (Qi et al. 1996). Additionally, in a process known as long-term depression (LTD), sustained low-frequency stimulation (LFS) results in desensitization of the synapses in normal hippocampal slices, however, $\mathrm{C} \beta 1$ null synapses were not subject to this phenomenon (Qi et al. 1996). Given the nature of these defects, and the tissue affected by $C \beta 1$ mutation, a role for PKA in contextual learning becomes more apparent.

Additional evidence for the role of PKA in learning and memory is found in mice harboring mutations that ablate all three splice variants of $\mathrm{C} \beta\left(\right.$ Prkacb $\left.^{-/}\right)$. $P r k a c b^{-1-}$ mice carry a targeted deletion of exon 2 , which is shared among splice variants, and results in phenotypically normal mice (Howe et al. 2002). Although the basal activity for PKA was significantly decreased in the amygdala, hippocampus, and cortex of Prkacb $^{-/-}$mice, loss of $\mathrm{C} \beta$ resulted in a compensatory increase in $\mathrm{C} \alpha$ expression, causing the activation potential for PKA in the brain to remain largely unaffected (Howe et al. 2002). Activation of PKA in both the amygdala and the hippocampus is known to play a role in learning and memory formation. Despite compensatory up-regulation of $\mathrm{C} \alpha, P r k a c b^{-1-}$ mice were less affected by cued fear conditioning, although these observations appear to be strain specific (Howe et al. 2002). Nevertheless, given that Prkacb[ $\beta 1]^{-/-}$ mice have impaired hippocampal synapse potentiation and Prkacb ${ }^{-1-}$ animals display learning defects despite compensation by $\mathrm{C} \alpha$, it is apparent that the activation of the specific isoforms of PKA catalytic subunits is essential for proper molecular signaling during learning and memory (Table 1).

To further address the role of PKA activation per total in the mouse, complete $\mathrm{KO}$ mice for both $\mathrm{C} \alpha$ subunits and $C \beta 1$ were generated (Huang et al. 2002). Complete KO of the catalytic subunits $\left(\right.$ Prkaca $^{-1-}$; $\left.\operatorname{Prkacb}[\beta 1]^{-/-}\right)$resulted in early embryonic lethality; however, when one allele of either $\mathrm{C} \alpha$ (including both splice variants) or $\mathrm{C} \beta 1$ remained unaffected (Prkaca $^{+/-} ;$Prkacb $[\beta 1]^{-/-}$or Prkaca $^{-/-}$; $\left.\operatorname{Prkacb}[\beta 1]^{+/-}\right)$, there were significant defects in neural tube development leading to spina bifida and/or 
Table 1 Phenotype of protein kinase A (PKA)-C subunit knockout mice

\begin{tabular}{lll}
\hline Genotype & \multicolumn{1}{c}{ Phenotype } & \multicolumn{1}{c}{ Reference } \\
\hline Prkaca $^{-/-}$ & $\begin{array}{l}\text { Growth deficiencies } \\
\text { Male infertility }\end{array}$ & Skalhegg et al. (2002) \\
${\text { Prkacb }[\beta 1]^{-/-}}$ & $\begin{array}{l}\text { Phenotypically normal } \\
\text { Deficiencies in neuronal signaling in hippocampus }\end{array}$ & Qi et al. (1996) \\
Prkacb $^{-/-}$ & $\begin{array}{l}\text { Phenotypically normal } \\
\text { Prkaca }\end{array}$ & Howe et al. (2002) \\
Prkaca $^{+/-} ;$Prkacb $[\beta 1]^{-/-}$ & Cued learning deficiencies (strain specific) \\
Prkaca $^{-/-} ;$Prkacb $[\beta 1]^{-/-}$ & Embryonically lethal & Huang et al. (2002) \\
& Spinal neural tube defects (100\%) & Huang et al. (2002) \\
& Embryonically lethal & Huang et al. (2002) \\
& Spinal neural tube defects (75\%) & \\
\hline
\end{tabular}

exencephaly. Although Prkaca ${ }^{+/-} ; \operatorname{Prkacb}[\beta 1]^{-/-}$ animals survived birth, all of them exhibited severe spina bifida resulting from failure of vertebral arch fusion at the dorsal midline between the forelimbs and hindlimbs. No Prkaca ${ }^{-/-} ;$Prkacb $[\beta 1]^{+/-}$animals survived gestation, and all of them exhibited severe neural tube defects leading to spina bifida. A small percentage $(25 \%)$ of these animals had additional cranial defects that led to exencephaly, although this phenotype was not observed in Prkaca $^{+/-}$; Prkacb $[\beta 1]^{-/-}$pups (Huang et al. 2002). Intriguingly, both Prkaca $^{-/-} ; \operatorname{Prkacb}[\beta 1]^{+/-}$and Prkaca ${ }^{+/-}$; Prkacb $[\beta 1]^{-/-}$embryos were histologically indistinguishable when looking at neural tube defects in early development. Also, both genotypes displayed morphological defects in dorsal root ganglia organization, with increased apoptosis and regression by embryonic day 12.5. Altogether, these observations point to an essential role for proper PKA activation that cannot be compensated regardless of the subunit affected. Furthermore, molecular analysis of these models suggests that during neural tube development, the role of PKA in suppressing Sonic hedgehog signaling is paramount for cells to undergo patterning and differentiation into the proper neural precursors that make up the adult spinal column (Huang et al. 2002).

It is clear in the cases of PKA catalytic subunit KO mice that precise on/off regulation of the enzyme is imperative for proper development of many of tissues. As mentioned above, in the testis it is essential that PKA is not activated during spermatogenesis, but its activity is vital to the function of mature spermatocytes. Furthermore, not only is on/off regulation important, but so is the regulation of the proper subunits in specific tissues. The C $\beta$ KO mice are a perfect example of how compensation by the $\mathrm{C} \alpha$ subunit is not enough to rescue the neuronal signaling deficits seen in these animals. Moreover, in the combinatorial KOs where a single allele of either $\mathrm{C} \alpha$ or $\mathrm{C} \beta 1$ is unaffected, the loss of the other three alleles cannot be compensated by the one remaining WT allele, regardless of the isoform. Altogether, these studies are highly insightful, and they elegantly exemplify the true complexities involved in PKA regulation during development and adulthood.

\section{PKA regulatory subunit KO mouse models}

Study of the PKA regulatory subunit KO models has reinforced prior knowledge, but has also led to new insights into the function of these gene products. Although described in detail below, this data is summarized in Table 2.

\section{Prkar1a KOs}

As noted above, PRKARlA/Prkarla is the most highly and widely expressed regulatory subunit of PKA. When the gene was knocked out from mice by replacing exon 3 of the gene with a Neomycin resistance cassette, homozygous null embryos died early during gestation due to a failure of normal mesodermal development (Amieux et al. 2002). Specifically, there was a failure of circulatory structures including the heart tube and other structures of the primitive vasculature. There was also a marked reduction in the size of axial and paraxial mesoderm, implying a generalized defect in mesodermal differentiation. Biochemical investigation of the mutant embryos revealed an enhanced basal PKA activity with a reduction in total PKA, consistent with the previous observation that free PKA has reduced stability within the cell (Hemmings 1986). Intriguingly, introduction of null alleles for Prkaca substantially improved the phenotype of Prkarla embryos, although it did not restore post-embryonic viability. This observation was interpreted to signify that the majority of the developmental effects were due to excess unregulated PKA activity. These same 
developmental defects were observed in mice homozygous for a different null allele for Prkarla, generated by removal of exon 2 from the Prkarla gene (Kirschner et al. 2005).

Although Prkarla $a^{-/-}$mice were not viable, heterozygotes (Prkarla ${ }^{+/-}$mice) did survive and were predicted to be a good genetic model for studying tumorigenesis associated with the $\mathrm{CNC}$ tumor predisposition (Kirschner et al. 2000a,b). Although the initial characterization of the animals did not indicate early signs of tumorigenesis (Amieux et al. 2002), more lengthy follow-up confirmed the tumorigenic nature of this genetic change. In an analysis of 17 animals up to 19 months of age, Veugelers et al. reported tumors in 12 mice $(57 \%)$ consisting primarily of sarcomas and some hepatocellular carcinomas. In an analysis of a larger group of mice up to 2 years old, our group described a somewhat different pattern of tumors, with a spectrum much more similar to those observed in patients with CNC (Kirschner et al. 2005). Specifically, we observed osteochondromyxomas in over $80 \%$ of mice, schwannomas in $33 \%$, and thyroid tumors in about $10 \%$ of animals. Unlike the pigmented schwannomas observed in CNC, the mouse schwannomas were not pigmented, but exhibited classical features of mouse Schwann cell tumors.

Because both alleles studies were well-defined nulls, it seems unlikely that the differences in the models related to residual Prkarla activity. Rather, it is more likely that the discrepancy is due to strain-specific differences between the models. Also, it appears that some of the tumors characterized by Veugelers et al. as calvarial 'sarcomas with myxomatous differentiation' may be the same tumors which we have classified as osteochondromyxomas by a combination of histological and immunohistochemical analysis (Pavel et al. 2008). Taken together, the complex phenotype of the Prkar1a ${ }^{+/-}$mice indicates that these animals serve as an excellent genetic model for human patients with $\mathrm{CNC}$.

\section{Prkar1b KOs}

In contrast to the Prkarla KOs, mice lacking Prkarlb are viable and fertile, and grossly normal in appearance (Brandon et al. 1995). Measurements of PKA activity from the brains of these animals did not reveal significant changes from WT, likely due to compensatory increases in levels of the Prkarla protein (Amieux et al. 1997). Because of the well-described association of PKA dysregulation with disruption in synaptic longterm potentiation (LTP; Abel \& Nguyen 2008), memory processes were studied in the Prkarlb mice. This analysis revealed defective hippocampal function, which affected multiple pathways. Prkarlb ${ }^{-/-}$animals exhibited deficient LTD at both the Shaffer collateral-CA1 synapse on pyramidal cells and the lateral perforant path-dentate synapse on granule cells. Also, depotentiation at CA1 synapse was also significantly reduced in mutant mice. It was concluded from these studies that Prkarlb is specifically required in the brain for LTD and depotentiation, as well as for LFS-induced LTD and may play a role in the long-term effects involving synaptic plasticity (Brandon et al. 1995). These findings that complemented the observations from the $\mathrm{C} \beta 1 \mathrm{KO}$ animals confirmed the role of this pathway in longterm memory affecting the CA3 pathway (Huang \& Kandel 1996).

\section{Prkar2a KOs}

Similar to the observations made with the Prkar1b null animals, mice lacking Prkar2a were healthy appearing and had no obvious phenotype (Burton et al. 1997). As in the Prkarla $a^{-/-}$mice, total levels of PKA activity

Table 2 Phenotype of protein kinase A (PKA)-R subunit knockout mice

\begin{tabular}{|c|c|c|}
\hline Genotype & Phenotype & Reference \\
\hline Prkar1a & $\begin{array}{l}\text { Embryonic lethal by e10.5, failure of mesodermally-derived structures, } \\
\text { notably heart and vasculature }\end{array}$ & $\begin{array}{l}\text { Amieux et al. (2002) and } \\
\text { Kirschner et al. (2005) }\end{array}$ \\
\hline Prkar1a $^{-1-} ;$ Prkaca $^{-1-}$ & $\begin{array}{l}\text { Partial rescue of phenotype, with restoration of mesodermal specification } \\
\text { and heart formation. Retains embryonic lethality but at a later date }\end{array}$ & Amieux et al. (2002) \\
\hline Prkar1a $^{-/-} ;$Prkaca $^{+/-}$ & 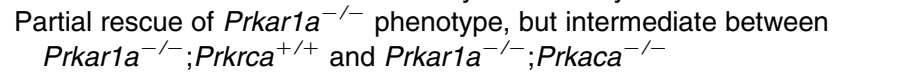 & Amieux et al. (2002) \\
\hline Prkar1b & Deficient long-term memory pathways & Brandon et al. (1995) \\
\hline Prkar2a & No clear phenotype & Burton et al. (1997) \\
\hline Prkar2b $b^{-1-}$ & Lean, resistant to diet-induced obesity. Impaired motor coordination & $\begin{array}{l}\text { Cummings et al. (1996) and } \\
\text { Brandon et al. (1998) }\end{array}$ \\
\hline Prkar2b $b^{-1-} ; U c p 1^{-1-}$ & Lean phenotype retained & Nolan et al. (2004) \\
\hline Prkar2b $b^{-/-} ; L e p^{o b / o b}$ & Rescue of obese phenotype & Newhall et al. (2005) \\
\hline Prkar2b $b^{-1-} ; A^{y}$ & Rescue of obese phenotype & Czyzyk et al. (2008) \\
\hline
\end{tabular}


were reduced in the $\operatorname{Prkar} 2 a^{-/-}$model, likely associated with post-transcript decreases in PKAC and increases in Prkar1a. Although it was hypothesized that disruption of Prkar2a would disrupt the interaction between PKA and the L-type calcium channels, significant changes in the relative subcellular distributions were not observed, suggesting that other PKAR subunits could substitute for this function of Prkar2a. To specifically probe the role of Prkar2a on CNS function, Prkar2 $a^{-1-}$ mice were analyzed for LTP and LTD in the visual cortex by studying ocular dominance plasticity (Rao et al. 2004). This analysis showed that mutant mice exhibited specific defects in LTP (but not LTD) with a resultant effect on visual cortex plasticity, indicating a unique role for Prkar2a in this process.

\section{Prkar2b KOs}

Mice lacking Prkar2b appeared morphologically normal and were fertile, although it was noted that the mice exhibited decreased adipose tissue (Cummings et al. 1996, Brandon et al. 1998). As in the other PKAR subunit KO models, levels of total PKA activity were reduced in the brains of these animals, resulting from compensation by up-regulation of Prkarla (Amieux et al. 1997). Because previous analyses had suggested that Prkar2b is the major PKAR subunit in the striatum, efforts were made to characterize the brain function of $\operatorname{Prkar} 2 b^{-1-}$ mice, particularly in regard to function of the dopaminergic system. Prkar $2 b^{-1-}$ mice showed an impaired ability to coordinate motor output while performing the rotarod task, and they exhibited increased locomotor sensitization to chronic amphetamine administration. Specific molecular changes were also observed in the brains of these animals, including reductions in both c-fos and dynorphin mRNAs. Overall, the CNS defects in Prkar $2 b^{-/-}$mice are attributable to a combination of relative PKA deficiency and the absence of correct subcellular localization (Brandon et al. 1998). These defects were proposed to affect dopamine-mediated gene expression changes, although acute locomotor effects were preserved.

In the adipose tissue, where Prkar2b is abundant, it was shown that RII $\beta$-containing holoenzyme has an important role in energy balance and adiposity. The Prkar $2 b^{-/-}$mice, even if apparently healthy and fertile, have markedly diminished white adipose tissue despite normal food intake. These mice do not develop diet-induced obesity or fatty livers, and consistently exhibit a lean phenotype (Cummings et al. 1996). The explanation for this observation is thought to lie in the fact that the isozyme switch to type 1 PKA induces a higher rate of metabolic uncoupling, leading to elevations of metabolic rate and body temperature, with enhanced energy utilization. Not only were these mice resistant to changes in body weight, but they also resisted diet-induced development of type 2 diabetes. Study of these animals showed that the RII $\beta$ KO mice have lower body weight, low insulin levels and improved total-body glucose disposal as compared with the WT controls, leading to the conclusion that loss of Prkar $2 b$ protects mice from diet-induced obesity, insulin resistance, and dyslipidemia (Schreyer et al. 2001).

A more detailed study in adipose tissue looked at the uncoupling protein 1 (UCP1) in Prkar $2 b^{-/-}$mice. UCP1 is primarily responsible for adaptive thermogenesis in response to sympathetic stimulation of the brown adipose tissue. Mice lacking Prkar2b exhibit nocturnal hyperactivity in addition to the increased oxygen consumption at rest. This study also analyzed Prkar $2 b^{-1-} ; U c p 1^{-1-}$ double KO mice, which retained the lean phenotype. This observation demonstrated that induction of UCP1 and increased resting oxygen consumption are not the cause of leanness in the Prkar2b $b^{-1-}$ mice (Nolan et al. 2004). In addition to this, experiments using leptin-deficient $L e p^{\mathrm{ob} / \mathrm{ob}}$ mice showed that the KO of Prkar $2 b$ provided substantial rescue of the obese phenotype. Basal oxygen consumption and nocturnal locomotor activity were increased, whereas body weight gain and food consumption decreased in the double mutant lacking both leptin and RII $\beta$ (Newhall et al. 2005). A similar finding was made for Agouti lethal yellow $\left(A^{y}\right)$ mice, another model of mouse obesity caused by ectopic expression of the MC4R antagonist Agouti protein (Czyzyk et al. 2008).

\section{Other generalized KO models affecting PKA signaling}

\section{PKI KOs}

Surprisingly, mice carrying a KO of Pkia $\left(\mathrm{Pkia}^{-/}\right)$ showed a fairly modest phenotype, with decreased basal and stimulated gene expression, which was attributed to a compensatory increase in Pkarla levels (Gangolli et al. 2000). The Pkib gene is highly expressed in the testes, and was predicted thought to have a strong reproductive phenotype. Again, KO of this gene produced a minimal phenotype, with normal reproductive ability in both males and females, either in isolation, or when crossed with the Pkia null mice. (Belyamani et al. 2001). Pkig has not been knocked out to date. 
AKAP KOs

Given the recent interest in the role of PKA localization, it is perhaps not surprising that the roles of the AKAPs are now being studied using KO mouse models (Mauban et al. 2009). In 2002, Akap4 was knocked out of mice (Miki et al. 2002). This X-linked AKAP is primarily expressed in the fibrous sheath of sperm; not surprisingly, these mice exhibited male infertility due to abnormal motility and structure. In 2005, one of the splice variants of Akap6 (mAKAP) was ablated by removing an alternatively spliced $5^{\prime}$-exon of the gene, leading to loss of the brainpredominant mAKAP $\alpha$ isoform of the protein (Michel et al. 2005). Mice lacking this exon expressed normal mAKAP $\beta$ in the heart, but were small and had early mortality. At the biochemical level, there was a loss of PDK1 localization, with evidence for loss of downstream activation of p90RSK in the mutant animals.

Recent reports have included KO models for Akapl (Newhall et al. 2006), Akap5 (Hall et al. 2007, Lu et al. 2007, Navedo et al. 2008, Schnizler et al. 2008, Tunquist et al. 2008), Akap8 (Yang et al. 2006), and Akap10 (Tingley et al. 2007), and Akap12. In each of these reports, ablation of the specific AKAPs has demonstrated important effects on PKA signaling in specific tissues, including findings in oocyte maturation (Akap1), cardiac function (Akap10), and most prominently in neuronal function (Akap5). These studies confirm the importance not only of PKA subunit abundance, but also of proper localization within the cell (Mauban et al. 2009).

\section{Understanding the function of PKA subunits by targeted gene KO models}

With use of global gene KO mouse models, the function of each different PKA subunit has been intensively explored in the process of development and physiology, and particularly in tumorigenesis (Brandon et al. 1995, Cummings et al. 1996, Burton et al. 1999, Amieux et al. 2002, Rao et al. 2004, Veugelers et al. 2004, Kirschner et al. 2005). However, the utility of these conventional KO mouse models was limited in observing phenotypes due to embryonic or neonatal lethality that prevented analysis of the impact of PKA subunits in postnatal and adult life. The emergence of the Cre-loxP system has overcome this disadvantage. The Cre (Causes recombination) protein of bacteriophage $\mathrm{P} 1$ directs recombination between loxP (locus of crossover P1) sites and deletes gene sequences that are flanked by two 34-bp loxP sites (floxed genes; Sauer \& Henderson 1988). By using the Cre-loxP system, researchers can investigate the role of a target gene at a specific tissue and/or at specific stages of development. Because conventional KO of Prkarlb, Prkar2a, or Prkar $2 b$ is viable and fertile (see above), it has not been necessary to pursue a conditional KO strategy for these genes. However, conditional $\mathrm{KO}$ of the Prkarla gene has proven a valuable model for understanding the relationship of mutation of this gene in tumorigenesis (Jones et al. 2008, Yin et al. 2008a,b). The Prkaca gene KOs also exhibit significant morbidity and early mortality; however, conditional KO alleles for this gene have not yet been described.

\section{Tissue-specific $\mathbf{R}$ subunit mouse modeling}

Heart-specific ablation of Prkar1a causes failure of heart development and myxomagenesis

As described above, mutations of PRKAR1A with consequent dysregulation of PKA activity are the cause of CNC in at least $50 \%$ of cases (Kirschner et al. $2000 a, b)$ or even higher at $65 \%$ from a recent analysis of a cohort of $51 \mathrm{CNC}$ probands (Veugelers et al. 2004), in which cardiac myxomas presents as one of its cardinal features. Approximately $30-60 \%$ of CNC patients will develop cardiac myxomas (Bertherat 2006), and cardiac myxomas are responsible for the death of more than $50 \%$ of patients (Stratakis et al. 2001). These tumors cannot be recapitulated by conventional Prkarla KO mice because Prkarla ${ }^{-1-}$ mice die by e9.5 without the development of heart tube (Amieux et al. 2002, Kirschner et al. 2005), whereas heterozygotes do not exhibit a cardiac phenotype (Veugelers et al. 2004, Kirschner et al. 2005). In order to better understand the tumorigenesis of cardiac myxoma, we generated heart-specific Prkar1a KO mouse model (Prkar1a-CKO) by utilizing the Cre-loxP system (Yin et al. 2008a,b), in which $\alpha$-myosin heavy chain $(\alpha-\mathrm{MHC})$ was used as the promoter to drive the expression of cre recombinase.

The Prkarla-CKOs exhibited marked thinning of ventricular walls, characterized by both hypoplasia of the compact layer and severely reduced trabeculation, and died embryonically at e11.5 (Fig. 2A and B). Strikingly, the Prkar1a-CKO hearts exhibited disorganization of the sarcomeres by ultrastructural analysis of cardiomyocyte architecture at 11.5. $\mathrm{Z}$ disks were easily seen, but they were not properly assembled, and myofilaments appeared loose and disarrayed. Most likely, the disorganized $\mathrm{Z}$ disks and myofilaments contribute to poor cardiac contraction and heart failure, causing demise of the growing embryo. 

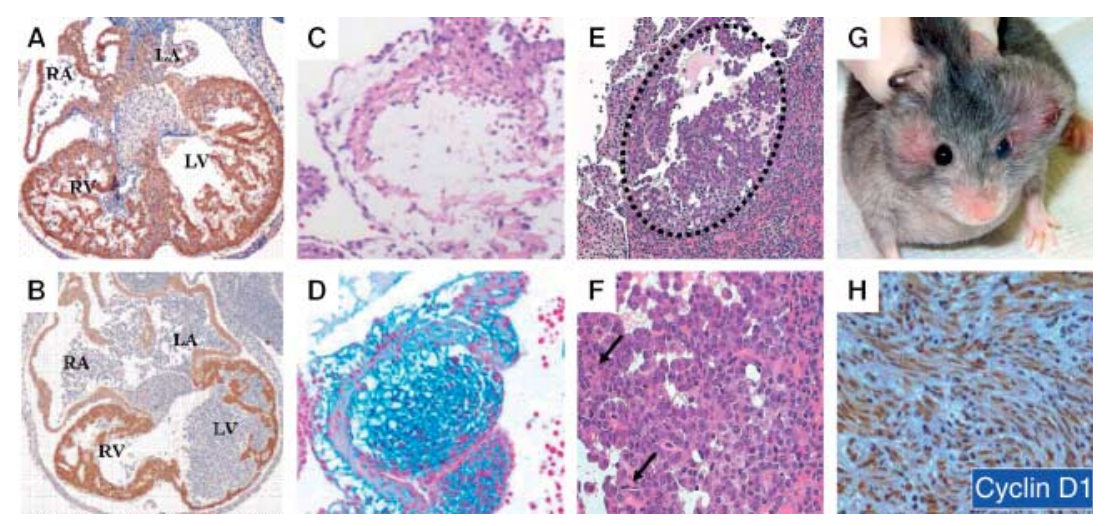

Figure 2 Pathology in tissue-specific Pkar1a knockouts. (A) Normal mouse heart at e11.5 stained for myosin to identify cardiomyocytes. (B) Dilated heart in cardiac-specific Prkar1a KO. (C and D) Myxomatous changes in the septa of Prkar1a-CKO heart, shown with $\mathrm{H}$ and $\mathrm{E}$ staining $(\mathrm{C})$ or by Alcian blue staining for extracellular matrix (D). (E) Pitiuitary microadenoma in a Prkar1a-PitKO mouse. (F) Higher power photomicrograph of the tumor showing mitotic Figures (arrows). (G) Gross appearance of tumors in a TEC3KO mouse. $(\mathrm{H})$ Cyclin D1 staining of a schwannoma showing overexpression of this protein. See text for details of each of these models.

At the cellular level, the thinning of ventricular walls was caused by the reduction of cardiomyocyte proliferation. In concordance with the reduced levels of the R1a regulatory subunit, hearts from Prkar1aCKO mice exhibited enhancement of both free and total PKA activity, similar to the observation in Prkarla ${ }^{-1-}$ mouse embryonic fibroblasts in vitro (Nadella \& Kirschner 2005). However, ablation of Prkarla did not cause compensation by the other regulatory subunits.

In Prkarla-CKO hearts, there was significant downregulation of all cardiac transcription factors investigated, including Srf, Nkx2-5, Gata4, and myocardin (Myocd), and also downstream targets, such as the cardiac structural proteins $\beta$-MHC and actins A1 (Acta1) and A2 (Acta2). The defective expression of Acta1 and Acta2 likely underlies the ultrastructural defect of sarcomeres. These effects of reduction in multiple transcription factors may be due to a direct effect of excess PKA activity on some gene transcription factors (via CREB) or may be an indirect effect on other transcription factors because PKA has previously been demonstrated to interfere with Srf activity (Davis et al. 2003, Nguyen et al. 2004). In addition, Srf can interact with Nkx2-5, GATA factors and Myocd to synergistically activate various transcriptional target genes (Bruneau 2002). The fact that transcription factors function in combination and in hierarchical networks (Durocher et al. 1997, Bruneau 2002) may explain why a reduction in multiple proteins, as observed here, causes synergistic and deleterious effects during cardiogenesis.

Very interestingly, $\sim 50 \%$ of Prkar1a-CKO hearts displayed stroma-rich lesions suggestive of human cardiac myxomas (Fig. 2C and D). At dissection of e11.5 mice, typical myxoid material was frequently noted in the endocardial cushion. This structure is composed of a subset of cells that undergo remodeling to form the valvular structures and membranous septa of the mature heart after cardiac looping (Person et al. 2005). This observation may help explain the observation that myxomas arise predominantly in the interatrial septum (Reynen 1995). With regard to the histogenesis of cardiac myxomas, this finding supports the hypothesis that cardiac myxomas originate from primitive pluripotent mesenchymal cells (Kinsella \& Fitzharris 1980, Person et al. 2005). Histologically, the majority of Prkar1a-CKO hearts exhibited the characteristic features of cardiac myxomas, including the presence of small numbers of polygonal or stellate cells surrounded by abundant loose stroma rich in acid mucopolysaccharides. Most strikingly, they also exhibit epithelium- or gland-like changes, which are rare but diagnostic features of human cardiac myxomas (Goldman et al. 1987, Johansson 1989). Finally, the tumors showed evidence of nuclear polymorphism and cellular atypia, as is typically seen only in neoplastic cells. Thus, the evidence is convincing that this mouse model develops early phases in the development of cardiac myxoma.

Although Prkar1a-CKO mice did not survive long enough to develop bona fide myxomas, they may still serve as the first good model with which to study the formation of cardiac myxomas. By applying an inducible Cre mouse line strategy, cardiac myxomas in close analogy to human patients may be generated in the future. 
Pituitary-specific ablation of Prkar1a causes pituitary tumorigenesis

Pituitary tumors are fairly common neoplasms in the population. A recent meta-analysis estimated the prevalence rate of pituitary adenomas to be $\sim 17 \%$ (Ezzat et al. 2004). Given the high frequency of pituitary adenomas and their potentially serious effects, the early diagnosis and treatment is very important for patients. However, little is known about the precise environmental and genetic factors involved in pituitary tumorigenesis. In CNC, GH-producing pituitary adenomas are observed in $\sim 10 \%$ of patients (Stratakis et al. 2001), and prolactinomas have also been reported in CNC kindreds (Stergiopoulos et al. 2004). In both of the Prkarla ${ }^{+/-}$mouse models described (Veugelers et al. 2004, Kirschner et al. 2005), pituitary pathology was not observed. Therefore, it was hypothesized that haploinsufficiency of Prkarla might not be sufficient to promote tumorigenesis and that complete loss of Prkar1a is necessary for tumor formation in the pituitary. To confirm this hypothesis, we used the rat GHRH receptor promoter to generate mice, which express the cre recombinase in pituitary cells of the Pit-1 lineage, which includes cells that produce $\mathrm{GH}$, prolactin (PRL), and TSH (Yin et al. 2008a,b). These mice were then crossed with Prkarla conditional null animals (Kirschner et al. 2005) to produce pituitaryspecific KO (Prkar1a-pitKO) mice (Yin et al. 2008a,b).

In contrast to the studies of Prkarla ${ }^{+/-}$mice, the Prkar1a-pitKOs developed pituitary tumors with high frequency (48\%) compared with controls (18\%; $P<0.05)$, although not until the advanced age of 18 months (Fig. 2E and F). Given the fact that it took the mice an extended period of time to develop tumors, it is possible that loss of Prkarla alone is not sufficient for tumorigenesis, and that a second genetic hit is required for tumor formation. Although prolactinomas were observed both in control and Prkarla-PitKO mice, non-prolactinomas exhibited much higher incidence rate in the Prkarla-pitKOs (29\%) compared with the controls $(4 \%, P<0.05)$. Characterization of these tumors demonstrated they were composed of cells of the Pit1 lineage that stained for GH, PRL, and TSH.

Interestingly, as is seen in CNC patients, PrkarlapitKO animals exhibited markedly elevated GH levels in serum compared with controls $(P<0.01)$, regardless of the presence of frank tumors. This may be of particular relevance given that there is a substantial portion of human patients with acromegaly that are not surgically cured of their disease. This model may therefore serve as a good model not only for the pituitary tumorigenesis but also as a model to test new therapies aimed at acromegaly in human patients.

\section{Tissue-specific ablation of Prkar1a in neural crest causes Schwannomas}

Schwannomas are observed in $\sim 14 \%$ of CNC patients (Stratakis et al. 2001) and have been designated as psammomatous melanotic schwannomas for their histopathologic appearance and high degree of pigmentation (Carney 1990, Martin-Reay et al. 1991).

In a Prkarla ${ }^{+/-}$mouse model, schwannomas were observed in $\sim 33 \%$ of animals, and facial neural crestspecific KO of the Prkarla gene recapitulated Schwann cell tumorigenesis (Kirschner et al. 2005). However, the role of Prkarla ablation on the pathways leading to Schwann cell tumorigenesis was unclear. To address this question, the TEC3 line was developed to express cre under the control of the enhancer-less Tyrosinase promoter, which enables transgene expression in a limited subset of facial neural crest derivatives (Tonks et al. 2003). This cre line was then crossed with mice carrying a conditional null allele of Prkarla (Kirschner et al. 2005) to generate tissue-specific KO mice (TEC3; Prkarla ${ }^{\text {loxP/loxP }}$, hence-forth called TEC3KO animals).

Observation of a cohort of 35 animals revealed that the penetrance of the tumor phenotype was $\sim 50 \%$ by 18 weeks and nearly $80 \%$ by 40 weeks (Fig. $2 \mathrm{G}$ and H; Jones et al. 2008). Histopathologically, these heterogeneous neoplasms were clinically classified as Genetically Engineered Mouse Schwannoma, grades II and III (Stemmer-Rachamimov et al. 2004).

Because schwannomas are also a cardinal feature of the inherited neurofibromatosis (NF) tumor syndromes, we studied the proteins responsible for both NF1 (Neurofibromin) and NF2 (Merlin) in Prkar1aassociated tumors. In TEC3KO schwannomas, the most striking observation was the marked downregulation of both Neurofibromin and Merlin in the tumors, shown both by immunofluorescence and by Western blot analysis, despite the fact that transcript levels of the NF1 and NF2 genes were increased, implying post-transcriptional regulation. It was previously reported that there are interactions between PKA and the NF proteins, as PKA is known to phosphorylate neurofibromin (Izawa et al. 1996, Tokuo et al. 2001), and loss of neurofibromin up-regulate cAMP levels, which would presumably increase PKA activity (Kim et al. 2001). There is also data indicating that PKA-mediated phosphorylation of the NF2 protein Merlin can affect its tumor suppressor function. (Alfthan et al. 2004, Laulajainen et al. 2008) function. We also observed down-regulation of Merlin 
in TEC3KO tumors (Jones et al. 2008), although the mechanism remains under investigation. These findings suggest that PKA may play a role in regulating the function and stability of the NF proteins.

Surprisingly, this unique model of Schwann cell tumorigenesis occurs in the absence of Ras (and therefore extracellular signal-regulated kinase, ERK or Akt) pathway activation, in contrast to Schwannomas caused by the ablation of neurofibromin. In the latter, loss of neurofibromin causes up-regulation of Ras signaling, thereby leading to activation of downstream effectors such as ERK and Akt (Cichowski et al. 2003, Dasgupta \& Gutmann 2005, Johannessen et al. 2005, 2008, Guilding et al. 2007). These results mimic earlier findings from our laboratory in Prkarla KO MEFs, which also showed that immortalization occurred independently of ERK or Akt activation (Nadella \& Kirschner 2005). Furthermore, in TEC3KO schwannomas, only Rac1 exhibited significant activation among the small $G$ proteins of Rho family, which is known to be involved in NF signaling (Pelton et al. 1998). There is good evidence that PKA can specifically affect the activity of Rac and Rho in cell type- and conditionspecific pattern (Howe 2004). In particular, PKA directly phosphorylates Rho at S188 and negatively regulates its activity (Ellerbroek et al. 2003), whereas Rac lacks a direct PKA phosphorylation site. Nevertheless, the effects of the activation of Rho and Rac on the pathway of TEC $3 \mathrm{KO}$ tumorigenesis need to be further explored.

In summary, PKA may have multiple roles in promoting Schwann cell tumorigenesis. First, it seems to modulate the stability of the NF proteins, such that dysregulation of PKA leads to posttranscriptional loss of these proteins during tumorigenesis. Secondly, PKA seems to signal, either directly or indirectly, to the same downstream effectors activated by mutations in the NF genes. However, unlike activation of Schwann cell tumorigenesis by NF mutations, PKA seems to promote tumorigenesis by a mechanism that excludes activation of Ras, ERK, and Akt. Thus, PKA promotes Schwann cell tumors by mechanisms that overlap but are distinct from those seen in NF associated tumorigenesis.

\section{Transgenic approaches to studying PKA signaling in the mouse}

\section{Generalized transgenics}

Because of the well-known association between activated G-proteins (such as in the MAS) and PKA signaling, efforts have been made to generate a transgenic mouse carrying an activated Gnasl gene.
Similar to the observations from human patients, mice carrying activated Gnas1 in all tissues do not survive gestation (Lee Weinstein, personal communication). This observation speaks to the requirement for control of PKA signaling during embryogenesis.

As a means to analyze the effect of loss of the Prkarla gene, Stratakis et al. generated a mouse containing an anti-sense transgene targeted to the Prkarla gene (Griffin et al. 2004a,b). This was placed under the control of a doxycycline-suppressible promoter to circumvent any problems with embryonic lethality. Despite the fact that Prkarla null mice exhibit embryonic lethality (Amieux et al. 2002, Kirschner et al. 2005), the Prkarla-antisense mice exhibited normal development. As they aged, the mice developed a variety of neoplastic lesions, including lymphomas, thyroid follicular adenomas, and mesenchymal tumors. Although the mouse demonstrated enhanced PKA activity (Griffin et al. 2004a,b), the connection between this observation and tumorigenesis was not completely clear, due to the potential presence of non-specific effects mediated by the anti-sense mRNA.

\section{Transgenic approaches targeted to specific tissues}

\section{Thyroid-specific transgenic models}

Determination of the role of PKA signaling in the mouse thyroid has been a topic that has been studied extensively. There is significant interest in understanding the connection between PKA signaling and human thyroid cancer because of recent studies indicating an increased risk of thyroid cancer associated with elevated TSH levels (Haymart et al. 2008a,b). The classic approach to activating PKA signaling in the mouse thyroid relies on treatment of mice with anti-thyroidal agents, thus raising TSH and driving PKA signaling. This process is more complex, though, as the TSH-R may signal through multiple G-protein pathways, including Gs, Gi, and Gq (Postiglione et al. 2002).

Transgenic approaches to studying PKA signaling by genetically manipulated mouse models have included various means of activating PKA signaling directly in the thyroid. To date, there are three genetic models that have studied the activation of the PKA signaling pathway in the thyroid. The earliest of these was the generation of transgenic mice carrying the A2-adenosine receptor in the thyroid gland by using the bovine thyroglobulin $(b T g)$ promoter to drive its expression (Ledent et al. 1992). This receptor signals essentially exclusively through Gs, and were generated to mimic constitutive signaling through the TSHR. These mice became significantly hyperthyroid with 
large thyroid goiters, and the mice died around 9 months of age from heart failure as a result of their severe hyperthyroidism. Although the glands were hyperplastic, no evidence of thyroid malignancy was observed, even when mice were treated with antithyroidal agents to prolong their lifespan.

Next, a transgenic line was generated by introducing a constitutively active mutant of the alpha subunit of the stimulatory G protein $\left(G N A S^{R 201 H}\right)$ into the thyroid by means of the same $b T g$ promoter (Michiels et al. 1994). The mutation, which is one of the mutations causing constitutive activation of the GNAS signaling, in MAS, causes unregulated production of cAMP. Despite their hyperthyroidism, these mice survived better than the $b T G-A 2 R$ transgenics, and the thyroid was studied up to 16 months of age. Overall, the thyroid phenotype was again similar, with toxic goiters developing, but no cancers. Finally, the most recent model, still dating back over 10 years ago, was the generation of mice carrying the Cholera toxin (CT) A1 subunit under the control of the rat $\mathrm{Tg}$ promoter (Zeiger et al. 1997). This CT-A1 subunit causes irreversible activation of Gs by catalyzing its ADPribosylation. Three Tg-CT lines were developed, with varying copy numbers of the transgene, leading to varying levels of cAMP production. In each of these lines, the mice eventually developed hyperthyroidism and hypertrophy, but again, no cancers. Additionally, a similar phenotype can be produced pharmacologically by the use of the anti-thyroid agents. In this case, the drug is given to make the mice profoundly hypothyroid, in which they develop marked TSH elevation and thyroid goiters. This model is considered a model of excess TSH stimulation, although unlike the models described above, the mice are hypothyroid, rather than hyperthyroid. When this treatment has been carried out for extended periods, thyroid cancers have not been observed (Jemec 1977).

\section{Heart-specific transgenic models}

Studies of PKA action in the heart have identified both positive and negative roles of PKA signaling in normal cardiac function. In the heart, cAMP production is classically mediated by the $\beta 1$ - and $\beta 2$-adrenergic receptors (Lohse \& Engelhardt 2001), although other receptors also utilize this same second messenger system (Mendez \& LaPointe 2005). PKA has multiple well-defined target proteins in the heart, including key functional proteins such as cardiac Troponin I (cTnI), the Ryanodine receptor 2 (Ryr2) and the sarcoplasmic $\mathrm{Ca}^{++}$-ATPase. These effects modulate the actions of catecholamines on cardiac function. Up-regulation of PKA activity has been posited to occur in the failing heart, as there is increased phosphorylation of PKA targets (Marx \& Marks 2002, Reiken et al. 2003), providing an explanation for the beneficial effects of $\beta$-blockade in these patients.

From a genetic point of view, dysregulation of the PKA system has been associated with abnormalities of heart function in mouse models (Lohse \& Engelhardt 2001), although corresponding human syndromes are generally unknown. Specific studies using transgenic mice to target the heart include the use of WT or mutant $\beta$-adrenergic receptors, present either at normal levels or overexpressed and thus constitutively active. In general, these studies have shown that chronic overexpression of the $\beta 1$-adrenergic receptors leads to cardiomyopathy and eventual heart failure (Engelhardt et al. 1999, Bisognano et al. 2000). This same phenotype was observed with expression of activated Gnasl (Vatner et al. 1998) or of the $\beta$-adrenergic receptor kinase (Koch et al. 1995), confirming the detrimental effects on chronic stimulation of this pathway. The data for the $\beta 2$-adrenergic receptor are a little more complicated, with moderate level expression of this receptor being tolerated, but high level expression causing significant cardiomyopathy (Liggett et al. 2000).

However, the situation is not quite so straightforward, as shown in studies with the type VI AC. When this protein was overexpressed in mice with cardiomyopathy-induced by overexpression of $\mathrm{G} \alpha-\mathrm{q}$ enhancement of cyclase increased survival, possibly by a mechanism that involves enhanced response to catecholamines (Roth et al. 1999, Rebolledo et al. 2006). However, transgenic expression of the same gene did not cause significant effects on heart rate or basal function (Roth et al. 2003), although it did improve survival in a coronary artery ligation model (Takahashi et al. 2006).

In a direct model, the PKAC subunit was introduced into the heart under the control of the $\alpha$-MHC promoter (Antos et al. 2001). Similar to the observations in the Prkarla cardiac KO animals (Yin et al. $2008 a, b)$, the mice developed dilated cardiomyopathy which correlated with the degree of transgene expression. These mice exhibited enhanced phosphorylation of the Ryr2 and the calcium handling protein phospholamban, in accordance with prior studies of heart failure.

An additional approach that has recently been studied is the effect of disrupting PKA localization in the heart. In this approach, a fragment of the AKAP AKAP13/ AKAP-Lbc, termed Ht-31 (Vijayaraghavan et al. 1997), is overexpressed in the cell. Owing to the competition for binding to PKA, primarily via the type 2 regulatory 
subunits, subcellular localization is disrupted. When Ht31 was expressed under an adenoviral control system, minimal effects were observed at baseline; however, stimulation with high doses of adrenergic agnostic led to reductions in phosphorylation of cTnI and caused enhanced $\beta$-adrenergic dependent cardiac contractility (McConnell et al. 2009).

An alternative approach to studying PKA signaling has been the use of a mutated form of the CREB transcription factor, which lacks the site for PKA (and other kinase) phosphorylation sites at S133. Targeting expression of this protein to the heart also produced dilated cardiomyopathy and electrophysiological changes (Fentzke et al. 1998, Zhu \& Saba 2003), again highlighting that either over- or under-activation of the PKA pathway produces deleterious changes.

\section{Brain-specific transgenic models}

One of the striking observations from PKAR subunit conventional KOs has been the general subtlety of the phenotypes. After careful investigation, CNS effects were observed in $\mathrm{KO}$ models for R1b (Brandon et al. 1995, Huang et al. 1995), R2a (Rao et al. 2004), and R2b (Brandon et al. 1998), as well as catalytic subunit KOs (Huang et al. 1995, Qi et al. 1996, Howe et al. 2002).

These observations parallel closely an extensive literature regarding the effects of PKA dysregulation in the CNS. The importance of PKA function for proper cognition in the mouse dates back to the late 90's when Abel et al. generated mice with a dominant negative form of the PKAR1 subunit known as R(AB), which has mutations in the cAMP-binding sites (Clegg et al. 1987). Transgenic mice expressing this cDNA under the control of the brain-directed CAMKII promoter exhibited defects in LTP, and important component of long-term memory (Abel et al. 1997). This system has formed the basis for extensive investigation on the genetics and biochemistry of memory associated with disruption of PKA, either by genetic means or by pharmacologic measures in isolated brain slices. This field has been recently reviewed extensively (Abel \& Nguyen 2008), and will not be discussed in detail, other than to note that all studies indicate the importance of proper PKA regulation in the establishment and maintenance of long-term memory, not only in mice, but in lower organisms as well.

\section{Neural crest models}

The McKnight group recently reported the development of a cre-inducible form of the $\mathrm{R}(\mathrm{AB})$ dominant negative Prkarla protein. In this model, the expression of $\mathrm{R}(\mathrm{AB})$ is blocked by a translational stop codon that is excised by cre-mediated recombination. When mice carrying this construct were crossed with mice expressing cre in the neural crest, the progeny exhibited lethal intestinal pseudo-obstruction, which was traced to a defect in the enteric ganglia (Howe et al. 2006). Although this allele of a dominant negative PKA has not yet been used extensively, it will provide another tool for further dissection PKA signaling pathways.

\section{Summary and future directions}

The cAMP-PKA signaling system has been known for over 40 years, and extensive work has gone into characterizing how stimulation or inhibition of this pathway affects cell function. Until recently, most of these studies were carried out in the context of immortalized tissue culture cells. Aside from problems associated with the presence of multiple genetic mutations that enable these cells to survive in culture, the use of a homogenous cell population in which intercellular communication is of minimal importance may undervalue the true role of this system, which appears to be involved in intercellular signaling in most tissues.

For this reason, the use of mouse models, which enable the assessment of genetic changes in the setting of an entire organism, allows a much better appreciation of the importance of this signaling system. The use of PKA subunit KOs has revealed the essential role of the Prkarla regulatory subunit and the nearessential role of the Prkaca catalytic subunit. The role of the other subunits in physiologic processes is much more subtle, with the exception of the Prkar2b subunit, which clearly has major roles in regulating both CNS function and fat metabolism.

As the study of PKA action moves forward, the tools are now in place to assess how these alterations affect signaling at the tissue level. Despite the fact that mice lacking Prkarla in Schwann cells develop tumorigenesis, this occurs independently of pathways thought to be important in vivo for tumor formation. As the signaling pathways affected by each of these KOs is traced at the molecular level, we should expect to gain important insights into direct signaling mechanisms, as well as how these pathways participate in important cross talk interactions.

Although this knowledge will be important for its own sake, the ultimate goal of these investigations will be to use the information for therapeutic purposes. Phosphodiesterase inhibitors, which prolong the cAMP-dependent signal, are already in use in clinical practice (sildenafil, tadalafil, etc.) and others have been tried (rolipram). Although disappointing so far, the study of the CNS functional alterations may lead to 
new therapies for disorders such as depression or for movement disorders. As we better understand how dysregulation of PKA causes tumors in the $\mathrm{CNC}$, in the thyroid, and in other organs (e.g. pituitary) this same approach may be used to affect tumor behavior and thereby lessen the impact of these diseases.

The availability of mouse models for these studies marks an important advance, which may lead to new developments in many of these fields. Stay tuned...

\section{Declaration of interest}

The authors declare that there is no conflict of interest that could be perceived as prejudicing the impartiality of the research reported.

\section{Funding}

This work was supported by the National Institute of Child Health and Human Development (grant number HD01323), the National Cancer Instutue (grant numbers CA112268 and CA16058), the US Army Medical Research and Materiel Command (grant number NF043067), and the Children's Tumor Foundation (grant number 2006-01-026).

\section{References}

Abel T \& Nguyen PV 2008 Regulation of hippocampusdependent memory by cyclic AMP-dependent protein kinase. Progress in Brain Research 169 97-115.

Abel T, Nguyen PV, Barad M, Deuel TA, Kandel ER \& Bourtchouladze R 1997 Genetic demonstration of a role for PKA in the late phase of LTP and in hippocampusbased long-term memory. Cell 88 615-626.

Alfthan K, Heiska L, Gronholm M, Renkema GH \& Carpen O 2004 Cyclic AMP-dependent protein kinase phosphorylates merlin at serine 518 independently of p21-activated kinase and promotes merlin-ezrin heterodimerization. Journal of Biological Chemistry 279 18559-18566.

Amieux PS, Cummings DE, Motamed K, Brandon EP, Wailes LA, Le K, Idzerda RL \& McKnight GS 1997 Compensatory regulation of RIalpha protein levels in protein kinase A mutant mice. Journal of Biological Chemistry 272 3993-3998.

Amieux PS, Howe DG, Knickerbocker H, Lee DC, Su T, Laszlo GS, Idzerda RL \& McKnight GS 2002 Increased basal cAMP-dependent protein kinase activity inhibits the formation of mesoderm-derived structures in the developing mouse embryo. Journal of Biological Chemistry 277 27294-27304.

Angelo R \& Rubin CS 1998 Molecular characterization of an anchor protein (AKAPCE) that binds the RI subunit (RCE) of type I protein kinase A from Caenorhabditis elegans. Journal of Biological Chemistry 273 14633-14643.

Antos CL, Frey N, Marx SO, Reiken S, Gaburjakova M, Richardson JA, Marks AR \& Olson EN 2001 Dilated cardiomyopathy and sudden death resulting from constitutive activation of protein kinase A. Circulation Research 89 997-1004.

Barlier A, Gunz G, Zamora AJ, Morange-Ramos I, FigarellaBranger D, Dufour H, Enjalbert A \& Jaquet P 1998 Pronostic and therapeutic consequences of Gs alpha mutations in somatotroph adenomas. Journal of Clinical Endocrinology and Metabolism 83 1604-1610.

Barradeau S, Imaizumi-Scherrer T, Weiss MC \& Faust DM 2000 Alternative $5^{\prime}$-exons of the mouse cAMP-dependent protein kinase subunit RIalpha gene are conserved and expressed in both a ubiquitous and tissue-restricted fashion. FEBS Letters 476 272-276.

Beene DL \& Scott JD 2007 A-kinase anchoring proteins take shape. Current Opinion in Cell Biology 19 192-198.

Belyamani M, Gangolli EA \& Idzerda RL 2001 Reproductive function in protein kinase inhibitor-deficient mice. Molecular and Cellular Biology 21 3959-3963.

Bertherat J 2006 Carney complex (CNC). Orphanet Journal of Rare Diseases 1-6.

Bertherat J, Groussin L, Sandrini F, Matyakhina L, Bei T, Stergiopoulos S, Papageorgiou T, Bourdeau I, Kirschner LS, Vincent-Dejean C et al. 2003 Molecular and functional analysis of PRKAR1A and its locus (17q22-24) in sporadic adrenocortical tumors: $17 \mathrm{q}$ losses, somatic mutations, and protein kinase A expression and activity. Cancer Research 63 5308-5319.

Bisognano JD, Weinberger HD, Bohlmeyer TJ, Pende A, Raynolds MV, Sastravaha A, Roden R, Asano K, Blaxall BC, Wu SC et al. 2000 Myocardial-directed overexpression of the human beta(1)-adrenergic receptor in transgenic mice. Journal of Molecular and Cellular Cardiology 32 817-830.

Brandon EP, Zhuo M, Huang YY, Qi M, Gerhold KA, Burton KA, Kandel ER, McKnight GS \& Idzerda RL 1995 Hippocampal long-term depression and depotentiation are defective in mice carrying a targeted disruption of the gene encoding the RI beta subunit of cAMP-dependent protein kinase. PNAS 92 8851-8855.

Brandon EP, Logue SF, Adams MR, Qi M, Sullivan SP, Matsumoto AM, Dorsa DM, Wehner JM, McKnight GS \& Idzerda RL 1998 Defective motor behavior and neural gene expression in RIIbeta-protein kinase A mutant mice. Journal of Neuroscience 18 3639-3649.

Bruneau BG 2002 Transcriptional regulation of vertebrate cardiac morphogenesis. Circulation Research 90 509-519.

Budovskaya YV, Stephan JS, Deminoff SJ \& Herman PK 2005 An evolutionary proteomics approach identifies substrates of the cAMP-dependent protein kinase. PNAS 102 13933-13938.

Burton KA, Johnson BD, Hausken ZE, Westenbroek RE, Idzerda RL, Scheuer T, Scott JD, Catterall WA \& McKnight GS 1997 Type II regulatory subunits are not required for the anchoring-dependent modulation of $\mathrm{Ca}^{2+}$ channel activity by cAMP-dependent protein kinase. PNAS 94 11067-11072. 
Burton KA, Treash-Osio B, Muller CH, Dunphy EL \& Mcknight GS 1999 Deletion of type llalpha regulatory subunit delocalizes protein kinase A in mouse sperm without affecting motility or fertilization. Journal of Biological Chemistry 274 24131-24136.

Burton KA, McDermott DA, Wilkes D, Poulsen MN, Nolan MA, Goldstein M, Basson CT \& McKnight GS 2006 Haploinsufficiency at the protein kinase A RI alpha gene locus leads to fertility defects in male mice and men. Molecular Endocrinology 20 2504-2513.

Carney JA 1990 Psammomatous melanotic schwannoma. A distinctive, heritable tumor with special associations, including cardiac myxoma and the Cushing syndrome. American Journal of Surgical Pathology 14 206-222.

Cetani F, Tonacchera M, Pinchera A, Barsacchi R, Basolo F, Miccoli P \& Pacini F 1999 Genetic analysis of the TSH receptor gene in differentiated human thyroid carcinomas. Journal of Endocrinological Investigation 22 273-278.

Cichowski K, Santiago S, Jardim M, Johnson BW \& Jacks T 2003 Dynamic regulation of the Ras pathway via proteolysis of the NF1 tumor suppressor. Genes and Development 17 449-454.

Clegg CH, Correll LA, Cadd GG \& McKnight GS 1987 Inhibition of intracellular cAMP-dependent protein kinase using mutant genes of the regulatory type I subunit. Journal of Biological Chemistry 262 13111-13119.

Conkright MD, Guzman E, Flechner L, Su AI, Hogenesch JB \& Montminy M 2003 Genome-wide analysis of CREB target genes reveals a core promoter requirement for cAMP responsiveness. Molecular Cell 11 1101-1108.

Corbin JD, Sugden PH, Lincoln TM \& Keely SL 1977 Compartmentalization of adenosine $3^{\prime}: 5^{\prime}$-monophosphate and adenosine $3^{\prime}: 5^{\prime}$-monophosphate-dependent protein kinase in heart tissue. Journal of Biological Chemistry 252 3854-3861.

Cummings DE, Brandon EP, Planas JV, Motamed K, Idzerda RL \& McKnight GS 1996 Genetically lean mice result from targeted disruption of the RII beta subunit of protein kinase A. Nature $382622-626$.

Czyzyk TA, Sikorski MA, Yang L \& McKnight GS 2008 Disruption of the RIIbeta subunit of PKA reverses the obesity syndrome of Agouti lethal yellow mice. PNAS 105 276-281.

Dasgupta B \& Gutmann DH 2005 Neurofibromin regulates neural stem cell proliferation, survival, and astroglial differentiation in vitro and in vivo. Journal of Neuroscience 25 5584-5594.

Davis A, Hogarth K, Fernandes D, Solway J, Niu J, Kolenko V, Browning D, Miano JM, Orlov SN \& Dulin NO 2003 Functional significance of protein kinase A activation by endothelin-1 and ATP: negative regulation of SRFdependent gene expression by PKA. Cellular Signalling 15 597-604.

Dell'Acqua ML, Smith KE, Gorski JA, Horne EA, Gibson ES \& Gomez LL 2006 Regulation of neuronal PKA signaling through AKAP targeting dynamics. European Journal of Cell Biology 85 627-633.
Desseyn JL, Burton KA \& McKnight GS 2000 Expression of a nonmyristylated variant of the catalytic subunit of protein kinase A during male germ-cell development. PNAS 97 6433-6438.

Diviani D, Baisamy L \& Appert-Collin A 2006 AKAP-Lbc: a molecular scaffold for the integration of cyclic AMP and Rho transduction pathways. European Journal of Cell Biology 85 603-610.

Dodge-Kafka KL, Soughayer J, Pare GC, Carlisle Michel JJ, Langeberg LK, Kapiloff MS \& Scott JD 2005 The protein kinase A anchoring protein mAKAP coordinates two integrated cAMP effector pathways. Nature 437 574-578.

Dodge-Kafka KL, Bauman A \& Kapiloff MS 2008 A-kinase anchoring proteins as the basis for cAMP signaling. Handbook of Experimental Pharmacology 186 3-14.

Durocher D, Charron F, Warren R, Schwartz RJ \& Nemer M 1997 The cardiac transcription factors Nkx2-5 and GATA-4 are mutual cofactors. EMBO Journal 16 5687-5696.

Ellerbroek SM, Wennerberg K \& Burridge K 2003 Serine phosphorylation negatively regulates RhoA in vivo. Journal of Biological Chemistry 278 19023-19031.

Engelhardt S, Hein L, Wiesmann F \& Lohse MJ 1999 Progressive hypertrophy and heart failure in beta1-adrenergic receptor transgenic mice. PNAS 96 7059-7064.

Ezzat S, Asa SL, Couldwell WT, Barr CE, Dodge WE, Vance ML \& McCutcheon IE 2004 The prevalence of pituitary adenomas: a systematic review. Cancer 101 613-619.

Feliciello A, Gottesman ME \& Avvedimento EV 2001 The biological functions of A-kinase anchor proteins. Journal of Molecular Biology 308 99-114.

Fentzke RC, Korcarz CE, Lang RM, Lin H \& Leiden JM 1998 Dilated cardiomyopathy in transgenic mice expressing a dominant-negative CREB transcription factor in the heart. Journal of Clinical Investigation 101 2415-2426.

Fuhrer D, Holzapfel HP, Wonerow P, Scherbaum WA \& Paschke R 1997a Somatic mutations in the thyrotropin receptor gene and not in the Gs alpha protein gene in 31 toxic thyroid nodules. Journal of Clinical Endocrinology and Metabolism 82 3885-3891.

Fuhrer D, Wonerow P, Willgerodt H \& Paschke R $1997 b$ Identification of a new thyrotropin receptor germline mutation (Leu629Phe) in a family with neonatal onset of autosomal dominant nonautoimmune hyperthyroidism. Journal of Clinical Endocrinology and Metabolism 82 4234-4238.

Gangolli EA, Belyamani M, Muchinsky S, Narula A, Burton KA, McKnight GS, Uhler MD \& Idzerda RL 2000 Deficient gene expression in protein kinase inhibitor alpha Null mutant mice. Molecular and Cellular Biology 20 3442-3448.

Gao X, Jin C, Ren J, Yao X \& Xue Y 2008 Proteome-wide prediction of PKA phosphorylation sites in eukaryotic kingdom. Genomics 92 457-463. 
Goldman BI, Frydman C, Harpaz N, Ryan SF \& Loiterman D 1987 Glandular cardiac myxomas. Histologic, immunohistochemical, and ultrastructural evidence of epithelial differentiation. Cancer 59 1767-1775.

Griffin KJ, Kirschner LS, Matyakhina L, Stergiopoulos S, Robinson-White A, Lenherr S, Weinberg FD, Claflin E, Meoli E, Cho-Chung YS et al. 2004a Down-regulation of regulatory subunit type $1 \mathrm{~A}$ of protein kinase A leads to endocrine and other tumors. Cancer Research 64 8811-8815.

Griffin KJ, Kirschner LS, Matyakhina L, Stergiopoulos SG, Robinson-White A, Lenherr SM, Weinberg FD, Claflin ES, Batista D, Bourdeau I et al. 2004b A transgenic mouse bearing an antisense construct of regulatory subunit type $1 \mathrm{~A}$ of protein kinase A develops endocrine and other tumours: comparison with Carney complex and other PRKAR1A induced lesions. Journal of Medical Genetics 41 923-931.

Gronholm M, Vossebein L, Carlson CR, Kuja-Panula J, Teesalu T, Alfthan K, Vaheri A, Rauvala H, Herberg FW, Tasken K et al. 2003 Merlin links to the cAMP neuronal signaling pathway by anchoring the RIbeta subunit of protein kinase A. Journal of Biological Chemistry 278 41167-41172.

Guilding C, McNair K, Stone TW \& Morris BJ 2007 Restored plasticity in a mouse model of neurofibromatosis type 1 via inhibition of hyperactive ERK and CREB. European Journal of Neuroscience 25 99-105.

Guthrie CR, Skalhegg BS \& McKnight GS 1997 Two novel brain-specific splice variants of the murine Cbeta gene of cAMP-dependent protein kinase. Journal of Biological Chemistry 272 29560-29565.

Hall DD, Davare MA, Shi M, Allen ML, Weisenhaus M, McKnight GS \& Hell JW 2007 Critical role of cAMPdependent protein kinase anchoring to the L-type calcium channel Cav1.2 via A-kinase anchor protein 150 in neurons. Biochemistry 46 1635-1646.

Harada A, Teng J, Takei Y, Oguchi K \& Hirokawa N 2002 MAP2 is required for dendrite elongation, PKA anchoring in dendrites, and proper PKA signal transduction. Journal of Cell Biology 158 541-549.

Haymart MR, Glinberg SL, Liu J, Sippel RS, Jaume JC \& Chen H $2008 a$ Higher serum TSH in thyroid cancer patients occurs independent of age and correlates with extrathyroidal extension. Clinical Endocrinology [in press].

Haymart MR, Repplinger DJ, Leverson GE, Elson DF, Sippel RS, Jaume JC \& Chen H $2008 b$ Higher serum thyroid stimulating hormone level in thyroid nodule patients is associated with greater risks of differentiated thyroid cancer and advanced tumor stage. Journal of Clinical Endocrinology and Metabolism 93 809-814.

Hemmings BA 1986 cAMP mediated proteolysis of the catalytic subunit of cAMP-dependent protein kinase. FEBS Letters 196 126-130.

Higuchi H, Yamashita T, Yoshikawa H \& Tohyama M 2003 PKA phosphorylates the $\mathrm{p} 75$ receptor and regulates its localization to lipid rafts. EMBO Journal 22 1790-1800.

Hino S, Tanji C, Nakayama KI \& Kikuchi A 2005

Phosphorylation of beta-catenin by cyclic AMPdependent protein kinase stabilizes beta-catenin through inhibition of its ubiquitination. Molecular and Cellular Biology 25 9063-9072.

Hoang T, Fenne IS, Cook C, Borud B, Bakke M, Lien EA \& Mellgren G 2004 cAMP-dependent protein kinase regulates ubiquitin-proteasome-mediated degradation and subcellular localization of the nuclear receptor coactivator GRIP1. Journal of Biological Chemistry 279 49120-49130.

Horvath A, Boikos S, Giatzakis C, Robinson-White A, Groussin L, Griffin KJ, Stein E, Levine E, Delimpasi G, Hsiao HP et al. 2006 A genome-wide scan identifies mutations in the gene encoding phosphodiesterase 11A4 (PDE11A) in individuals with adrenocortical hyperplasia. Nature Genetics 38 794-800.

Horvath A, Giatzakis C, Tsang K, Greene E, Osorio P, Boikos S, Libe R, Patronas Y, Robinson-White A, Remmers E et al. 2008 A cAMP-specific phosphodiesterase (PDE8B) that is mutated in adrenal hyperplasia is expressed widely in human and mouse tissues: a novel PDE8B isoform in human adrenal cortex. European Journal of Human Genetics 16 1245-1253.

Howe AK 2004 Regulation of actin-based cell migration by cAMP/PKA. Biochimica et Biophysica Acta 1692 159-174.

Howe DG, Wiley JC \& McKnight GS 2002 Molecular and behavioral effects of a null mutation in all PKA $\mathrm{C}$ beta isoforms. Molecular and Cellular Neurosciences 20 515-524.

Howe DG, Clarke CM, Yan H, Willis BS, Schneider DA, McKnight GS \& Kapur RP 2006 Inhibition of protein kinase $\mathrm{A}$ in murine enteric neurons causes lethal intestinal pseudo-obstruction. Journal of Neurobiology 66 256-272.

Huang YY \& Kandel ER 1996 Modulation of both the early and the late phase of mossy fiber LTP by the activation of beta-adrenergic receptors. Neuron 16 611-617.

Huang YY, Kandel ER, Varshavsky L, Brandon EP, Qi M, Idzerda RL, McKnight GS \& Bourtchouladze R 1995 A genetic test of the effects of mutations in PKA on mossy fiber LTP and its relation to spatial and contextual learning. Cell 83 1211-1222.

Huang W, Zhou X, Lefebvre V \& de Crombrugghe B 2000 Phosphorylation of SOX9 by cyclic AMP-dependent protein kinase A enhances SOX9's ability to transactivate a Col2a1 chondrocyte-specific enhancer. Molecular and Cellular Biology 20 4149-4158.

Huang Y, Roelink H \& McKnight GS 2002 Protein kinase A deficiency causes axially localized neural tube defects in mice. Journal of Biological Chemistry 277 19889-19896.

Huang SY, Tsai ML, Chen GY, Wu CJ \& Chen SH 2007 A systematic MS-based approach for identifying in vitro substrates of PKA and PKG in rat uteri. Journal of Proteome Research 6 2674-2684. 
Izawa I, Tamaki N \& Saya H 1996 Phosphorylation of neurofibromatosis type 1 gene product (neurofibromin) by cAMP-dependent protein kinase. FEBS Letters 382 53-59.

Jarnaess E \& Tasken K 2007 Spatiotemporal control of cAMP signalling processes by anchored signalling complexes. Biochemical Society Transactions 35 931-937.

Jemec B 1977 Studies of the tumorigenic effect of two goitrogens. Cancer 40 2188-2202.

Johannessen CM, Reczek EE, James MF, Brems H, Legius E \& Cichowski K 2005 The NF1 tumor suppressor critically regulates TSC2 and mTOR. PNAS 102 8573-8578.

Johannessen CM, Johnson BW, Williams SM, Chan AW, Reczek EE, Lynch RC, Rioth MJ, McClatchey A, Ryeom S \& Cichowski K 2008 TORC1 is essential for NF1associated malignancies. Current Biology 18 56-62.

Johansson L 1989 Histogenesis of cardiac myxomas. An immunohistochemical study of 19 cases, including one with glandular structures, and review of the literature. Archives of Pathology and Laboratory Medicine 113 735-741.

Jones GN, Tep C, Towns WH, Mihai G, Tonks ID, Kay GF, Schmalbrock P, Stemmer-Rachamimov AO, Yoon SO \& Kirschner LS 2008 Tissue-specific ablation of Prkarla causes Schwannomas by suppressing NF protein production. Neoplasia 10 1213-1221.

Kaltsas GA, Kola B, Borboli N, Morris DG, Gueorguiev M, Swords FM, Czirjak S, Kirschner LS, Stratakis CA, Korbonits M et al. 2002 Sequence analysis of the PRKAR1A gene in sporadic somatotroph and other pituitary tumours. Clinical Endocrinology 57 443-448.

Kim HA, Ratner N, Roberts TM \& Stiles CD 2001 Schwann cell proliferative responses to cAMP and Nf1 are mediated by cyclin D1. Journal of Neuroscience 21 1110-1116.

Kinsella MG \& Fitzharris TP 1980 Origin of cushion tissue in the developing chick heart: cinematographic recordings of in situ formation. Science 207 1359-1360.

Kirschner LS, Carney JA, Pack SD, Taymans SE, Giatzakis C, Cho YS, Cho-Chung YS \& Stratakis CA 2000a Mutations of the gene encoding the protein kinase A type I-alpha regulatory subunit in patients with the Carney complex. Nature Genetics 26 89-92.

Kirschner LS, Sandrini F, Monbo J, Lin JP, Carney JA \& Stratakis CA $2000 b$ Genetic heterogeneity and spectrum of mutations of the PRKAR1A gene in patients with the Carney complex. Human Molecular Genetics 9 3037-3046.

Kirschner LS, Kusewitt DF, Matyakhina L, Towns WH II, Carney JA, Westphal H \& Stratakis CA 2005 A mouse model for the Carney complex tumor syndrome develops neoplasia in cyclic AMP-responsive tissues. Cancer Research 65 4506-4514.

Koch WJ, Rockman HA, Samama P, Hamilton RA, Bond RA, Milano CA \& Lefkowitz RJ 1995 Cardiac function in mice overexpressing the beta-adrenergic receptor kinase or a beta ARK inhibitor. Science 268 1350-1353.

Lania AG, Mantovani G, Ferrero S, Pellegrini C, Bondioni S, Peverelli E, Braidotti P, Locatelli M, Zavanone ML, Ferrante E et al. 2004 Proliferation of transformed somatotroph cells related to low or absent expression of protein kinase a regulatory subunit $1 \mathrm{~A}$ protein. Cancer Research 64 9193-9198.

Laulajainen M, Muranen T, Carpen O \& Gronholm M 2008 Protein kinase A-mediated phosphorylation of the NF2 tumor suppressor protein merlin at serine 10 affects the actin cytoskeleton. Oncogene 27 3233-3243.

Ledent C, Dumont JE, Vassart G \& Parmentier M 1992 Thyroid expression of an A2 adenosine receptor transgene induces thyroid hyperplasia and hyperthyroidism. EMBO Journal 11 537-542.

Liggett SB, Tepe NM, Lorenz JN, Canning AM, Jantz TD, Mitarai S, Yatani A \& Dorn GW II 2000 Early and delayed consequences of beta(2)-adrenergic receptor overexpression in mouse hearts: critical role for expression level. Circulation 101 1707-1714.

Lohse MJ \& Engelhardt S 2001 Protein kinase a transgenes: the many faces of cAMP. Circulation Research 89 938-940.

Lu Y, Allen M, Halt AR, Weisenhaus M, Dallapiazza RF, Hall DD, Usachev YM, McKnight GS \& Hell JW 2007 Age-dependent requirement of AKAP150-anchored PKA and GluR2-lacking AMPA receptors in LTP. EMBO Journal 26 4879-4890.

Manning G, Whyte DB, Martinez R, Hunter T \& Sudarsanam S 2002 The protein kinase complement of the human genome. Science 298 1912-1934.

Martin-Reay DG, Shattuck MC \& Guthrie FW Jr 1991 Psammomatous melanotic schwannoma: an additional component of Carney's complex. Report of a case. American Journal of Clinical Pathology 95 484-489.

Marx SO \& Marks AR 2002 Regulation of the ryanodine receptor in heart failure. Basic Research in Cardiology 97 I49-I51.

Mason HS, Latten MJ, Godoy LD, Horowitz B \& Kenyon JL 2002 Modulation of Kv1.5 currents by protein kinase A, tyrosine kinase, and protein tyrosine phosphatase requires an intact cytoskeleton. Molecular Pharmacology 61 285-293.

Mauban JR, O’Donnell M, Warrier S, Manni S \& Bond M 2009 AKAP-scaffolding proteins and regulation of cardiac physiology. Physiology 24 78-87.

Mayr B \& Montminy M 2001 Transcriptional regulation by the phosphorylation-dependent factor CREB. Nature Reviews. Molecular Cell Biology 2 599-609.

McConnachie G, Langeberg LK \& Scott JD 2006 AKAP signaling complexes: getting to the heart of the matter. Trends in Molecular Medicine 12 317-323.

McConnell BK, Popovic Z, Mal N, Lee K, Bautista J, Forudi F, Schwartzman R, Jin JP, Penn M \& Bond M 2009 Disruption of protein kinase A interaction with A-kinase-anchoring proteins in the heart in vivo: effects on cardiac contractility, protein kinase A phosphorylation, and troponin I proteolysis. Journal of Biological Chemistry 284 1583-1592.

Mendez M \& LaPointe MC 2005 PGE2-induced hypertrophy of cardiac myocytes involves EP4 receptor-dependent activation of p42/44 MAPK and EGFR transactivation. American Journal of Physiology. Heart and Circulatory Physiology 288 H2111-H2117. 
Michel JJ \& Scott JD 2002 AKAP mediated signal transduction. Annual Review of Pharmacology and Toxicology 42 235-257.

Michel JJ, Townley IK, Dodge-Kafka KL, Zhang F, Kapiloff MS \& Scott JD 2005 Spatial restriction of PDK1 activation cascades by anchoring to mAKAPalpha. Molecular Cell 20 661-672.

Michiels FM, Caillou B, Talbot M, Dessarps-Freichey F, Maunoury MT, Schlumberger M, Mercken L, Monier R \& Feunteun J 1994 Oncogenic potential of guanine nucleotide stimulatory factor alpha subunit in thyroid glands of transgenic mice. PNAS 91 10488-10492.

Miki K, Willis WD, Brown PR, Goulding EH, Fulcher KD \& Eddy EM 2002 Targeted disruption of the Akap4 gene causes defects in sperm flagellum and motility. Developmental Biology 248 331-342.

Montminy M 1997 Transcriptional regulation by cyclic AMP. Annual Review of Biochemistry 66 807-822.

Nadella KS \& Kirschner LS 2005 Disruption of protein kinase a regulation causes immortalization and dysregulation of D-type cyclins. Cancer Research 65 10307-10315.

Navedo MF, Nieves-Cintron M, Amberg GC, Yuan C, Votaw VS, Lederer WJ, McKnight GS \& Santana LF 2008 AKAP150 is required for stuttering persistent $\mathrm{Ca}^{2+}$ sparklets and angiotensin II-induced hypertension. Circulation Research 102 e1-e11.

Neuberger G, Schneider G \& Eisenhaber F 2007 pkaPS: prediction of protein kinase A phosphorylation sites with the simplified kinase-substrate binding model. Biology Direct 21.

Newhall KJ, Cummings DE, Nolan MA \& McKnight GS 2005 Deletion of the RIIbeta-subunit of protein kinase A decreases body weight and increases energy expenditure in the obese, leptin-deficient ob/ob mouse. Molecular Endocrinology 19 982-991.

Newhall KJ, Criniti AR, Cheah CS, Smith KC, Kafer KE, Burkart AD \& McKnight GS 2006 Dynamic anchoring of PKA is essential during oocyte maturation. Current Biology 16 321-327.

Nguyen GH, French R \& Radhakrishna H 2004 Protein kinase A inhibits lysophosphatidic acid induction of serum response factor via alterations in the actin cytoskeleton. Cellular Signalling 16 1141-1151.

Nolan MA, Sikorski MA \& McKnight GS 2004 The role of uncoupling protein 1 in the metabolism and adiposity of RII beta-protein kinase A-deficient mice. Molecular Endocrinology 18 2302-2311.

Noveen A, Jiang TX \& Chuong CM 1996 cAMP, an activator of protein kinase A, suppresses the expression of sonic hedgehog. Biochemical and Biophysical Research Communications 219 180-185.

Oksvold MP, Funderud A, Kvissel AK, Skarpen E, Henanger H, Huitfeldt HS, Skalhegg BS \& Orstavik S 2008 Epidermal growth factor receptor levels are reduced in mice with targeted disruption of the protein kinase A catalytic subunit. BMC Cell Biology 916.

Palos-Paz F, Perez-Guerra O, Cameselle-Teijeiro J, RuedaChimeno C, Barreiro-Morandeira F, Lado-Abeal J,
Araujo Vilar D, Argueso R, Barca O, Botana M et al. 2008 Prevalence of mutations in TSHR, GNAS, PRKAR1A and RAS genes in a large series of toxic thyroid adenomas from Galicia, an iodine-deficient area in NW Spain. European Journal of Endocrinology 159 623-631.

Parma J, Duprez L, Van Sande J, Cochaux P, Gervy C, Mockel J, Dumont J \& Vassart G 1993 Somatic mutations in the thyrotropin receptor gene cause hyperfunctioning thyroid adenomas. Nature 365 649-651.

Parma J, Duprez L, Van Sande J, Hermans J, Rocmans P, Van Vliet G, Costagliola S, Rodien P, Dumont JE \& Vassart G 1997 Diversity and prevalence of somatic mutations in the thyrotropin receptor and Gs alpha genes as a cause of toxic thyroid adenomas. Journal of Clinical Endocrinology and Metabolism 82 2695-2701.

Pavel E, Nadella K, Towns WH II \& Kirschner LS 2008 Mutation of Prkarla causes osteoblast neoplasia driven by dysregulation of protein kinase A. Molecular Endocrinology 22 430-440.

Pelton PD, Sherman LS, Rizvi TA, Marchionni MA, Wood P, Friedman RA \& Ratner N 1998 Ruffling membrane, stress fiber, cell spreading and proliferation abnormalities in human Schwannoma cells. Oncogene 17 2195-2209.

Person AD, Klewer SE \& Runyan RB 2005 Cell biology of cardiac cushion development. International Review of Cytology 243 287-335.

Postiglione MP, Parlato R, Rodriguez-Mallon A, Rosica A, Mithbaokar P, Maresca M, Marians RC, Davies TF, Zannini MS, De Felice M et al. 2002 Role of the thyroid-stimulating hormone receptor signaling in development and differentiation of the thyroid gland. PNAS 99 15462-15467.

Qi M, Zhuo M, Skalhegg BS, Brandon EP, Kandel ER, McKnight GS \& Idzerda RL 1996 Impaired hippocampal plasticity in mice lacking the Cbeta1 catalytic subunit of cAMP-dependent protein kinase. PNAS 93 1571-1576.

Qiao J, Huang F \& Lum H 2003 PKA inhibits RhoA activation: a protection mechanism against endothelial barrier dysfunction. American Journal of Physiology. Lung Cellular and Molecular Physiology 284 L972-L980.

Rannels SR, Cobb CE, Landiss LR \& Corbin JD 1985 The regulatory subunit monomer of cAMP-dependent protein kinase retains the salient kinetic properties of the native dimeric subunit. Journal of Biological Chemistry 260 3423-3430.

Rao Y, Fischer QS, Yang Y, McKnight GS, LaRue A \& Daw NW 2004 Reduced ocular dominance plasticity and longterm potentiation in the developing visual cortex of protein kinase A RII alpha mutant mice. European Journal of Neuroscience 20 837-842.

Rebolledo B, Lai NC, Gao MH, Takahashi T, Roth DM, Baird SM \& Hammond HK 2006 Adenylylcyclase gene transfer increases function of the failing heart. Human Gene Therapy 17 1043-1048.

Reiken S, Gaburjakova M, Guatimosim S, Gomez AM, D'Armiento J, Burkhoff D, Wang J, Vassort G, Lederer WJ 
\& Marks AR 2003 Protein kinase A phosphorylation of the cardiac calcium release channel (ryanodine receptor) in normal and failing hearts. Role of phosphatases and response to isoproterenol. Journal of Biological Chemistry 278 444-453.

Reynen K 1995 Cardiac Myxomas. New England Journal of Medicine 333 1610-1617.

Robinson-Steiner AM, Beebe SJ, Rannels SR \& Corbin JD 1984 Microheterogeneity of type II cAMP-dependent protein kinase in various mammalian species and tissues. Journal of Biological Chemistry 259 10596-10605.

Rolli-Derkinderen M, Sauzeau V, Boyer L, Lemichez E, Baron C, Henrion D, Loirand G \& Pacaud P 2005 Phosphorylation of serine 188 protects RhoA from ubiquitin/proteasome-mediated degradation in vascular smooth muscle cells. Circulation Research 96 1152-1160.

Rosenberg D, Groussin L, Jullian E, Perlemoine K, Bertagna X \& Bertherat J 2002 Role of the PKA-regulated transcription factor CREB in development and tumorigenesis of endocrine tissues. Annals of the New York Academy of Sciences 968 65-74.

Roth DM, Gao MH, Lai NC, Drumm J, Dalton N, Zhou JY, Zhu J, Entrikin D \& Hammond HK 1999 Cardiac-directed adenylyl cyclase expression improves heart function in murine cardiomyopathy. Circulation 99 3099-3102.

Roth DM, Drumm JD, Bhargava V, Swaney JS, Gao MH \& Hammond HK 2003 Cardiac-directed expression of adenylyl cyclase and heart rate regulation. Basic Research in Cardiology 98 380-387.

Ruehr ML, Russell MA \& Bond M 2004 A-kinase anchoring protein targeting of protein kinase A in the heart. Journal of Molecular and Cellular Cardiology 37 653-665.

Russo D, Arturi F, Schlumberger M, Caillou B, Monier R, Filetti S \& Suarez HG 1995 Activating mutations of the TSH receptor in differentiated thyroid carcinomas. Oncogene 11 1907-1911.

San Agustin JT \& Witman GB 2001 Differential expression of the $\mathrm{C}(\mathrm{s})$ and Calpha1 isoforms of the catalytic subunit of cyclic $3^{\prime}, 5^{\prime}$-adenosine monophosphate-dependent protein kinase testicular cells. Biology of Reproduction 65 151-164.

Sandrini F, Kirschner LS, Bei T, Farmakidis C, YasufukuTakano J, Takano K, Prezant TR, Marx SJ, Farrell WE, Clayton RN et al. $2002 a$ PRKAR1A, one of the Carney complex genes, and its locus (17q22-24) are rarely altered in pituitary tumours outside the Carney complex. Journal of Medical Genetics 39 e78.

Sandrini F, Matyakhina L, Sarlis NJ, Kirschner LS, Farmakidis C, Gimm O \& Stratakis CA 2002b Regulatory subunit type I-alpha of protein kinase A (PRKAR1A): a tumor-suppressor gene for sporadic thyroid cancer. Genes, Chromosomes and Cancer 35 182-192.

Sauer B \& Henderson N 1988 DNA recombination in mammalian cells by the Cre recombinase of bacteriophage P1. PNAS 85 5166-5170.

Schnizler K, Shutov LP, Van Kanegan MJ, Merrill MA, Nichols B, McKnight GS, Strack S, Hell JW \& Usachev
YM 2008 Protein kinase A anchoring via AKAP150 is essential for TRPV1 modulation by forskolin and prostaglandin E2 in mouse sensory neurons. Journal of Neuroscience 28 4904-4917.

Schreyer SA, Cummings DE, McKnight GS \& LeBoeuf RC 2001 Mutation of the RIIbeta subunit of protein kinase A prevents diet-induced insulin resistance and dyslipidemia in mice. Diabetes 50 2555-2562.

Shenker A, Weinstein LS, Sweet DE \& Spiegel AM 1994 An activating Gs alpha mutation is present in fibrous dysplasia of bone in the McCune-Albright syndrome. Journal of Clinical Endocrinology and Metabolism 79 750-755.

Skalhegg BS \& Tasken K 2000 Specificity in the cAMP/PKA signaling pathway. Differential expression, regulation, and subcellular localization of subunits of PKA. Frontiers in Bioscience 5 D678-D693.

Skalhegg BS, Huang Y, Su T, Idzerda RL, McKnight GS \& Burton KA 2002 Mutation of the Calpha subunit of PKA leads to growth retardation and sperm dysfunction. Molecular Endocrinology 16 630-639.

Solberg R, Sandberg M, Natarajan V, Torjesen PA, Hansson V, Jahnsen T \& Tasken K 1997 The human gene for the regulatory subunit RI alpha of cyclic adenosine $3^{\prime}, 5^{\prime}$ monophosphate-dependent protein kinase: two distinct promoters provide differential regulation of alternately spliced messenger ribonucleic acids. Endocrinology 138 169-181.

Stemmer-Rachamimov AO, Louis DN, Nielsen GP, Antonescu CR, Borowsky AD, Bronson RT, Burns DK, Cervera P, McLaughlin ME, Reifenberger G et al. 2004 Comparative pathology of nerve sheath tumors in mouse models and humans. Cancer Research 64 3718-3724.

Stergiopoulos SG, Abu-Asab MS, Tsokos M \& Stratakis CA 2004 Pituitary pathology in Carney complex patients. Pituitary 7 73-82.

Stratakis CA, Kirschner LS \& Carney JA 2001 Clinical and molecular features of the Carney complex: diagnostic criteria and recommendations for patient evaluation. Journal of Clinical Endocrinology and Metabolism 86 4041-4046.

Sun F, Hug MJ, Bradbury NA \& Frizzell RA 2000 Protein kinase A associates with cystic fibrosis transmembrane conductance regulator via an interaction with ezrin. Journal of Biological Chemistry 275 14360-14366.

Sutherland EW \& Rall TW 1958 Fractionation and characterization of a cyclic adenine ribonucleotide formed by tissue particles. Journal of Biological Chemistry 232 1077-1091.

Takahashi T, Tang T, Lai NC, Roth DM, Rebolledo B, Saito M, Lew WY, Clopton P \& Hammond HK 2006 Increased cardiac adenylyl cyclase expression is associated with increased survival after myocardial infarction. Circulation 114 388-396.

Tamaki H 2007 Glucose-stimulated cAMP-protein kinase A pathway in yeast Saccharomyces cerevisiae. Journal of Bioscience and Bioengineering 104 245-250. 
The I, Hannigan GE, Cowley GS, Reginald S, Zhong Y, Gusella JF, Hariharan IK \& Bernards A 1997 Rescue of a Drosophila NF1 mutant phenotype by protein kinase A. Science 276 791-794.

Thevelein JM, Bonini BM, Castermans D, Haesendonckx S, Kriel J, Louwet W, Thayumanavan P, Popova Y, Rubio-Texeira M, Schepers W et al. 2008 Novel mechanisms in nutrient activation of the yeast protein kinase A pathway. Acta Microbiologica et Immunologica Hungarica 55 75-89.

Tingley WG, Pawlikowska L, Zaroff JG, Kim T, Nguyen T, Young SG, Vranizan K, Kwok PY, Whooley MA \& Conklin BR 2007 Gene-trapped mouse embryonic stem cell-derived cardiac myocytes and human genetics implicate AKAP10 in heart rhythm regulation. PNAS 104 8461-8466.

Tokuo H, Yunoue S, Feng L, Kimoto M, Tsuji H, Ono T, Saya H \& Araki N 2001 Phosphorylation of neurofibromin by cAMP-dependent protein kinase is regulated via a cellular association of $\mathrm{N}(\mathrm{G}), \mathrm{N}(\mathrm{G})$-dimethylarginine dimethylaminohydrolase. FEBS Letters 494 48-53.

Tonks ID, Nurcombe V, Paterson C, Zournazi A, Prather C, Mould AW \& Kay GF 2003 Tyrosinase-Cre mice for tissue-specific gene ablation in neural crest and neuroepithelial-derived tissues. Genesis 37 131-138.

Tunquist BJ, Hoshi N, Guire ES, Zhang F, Mullendorff K, Langeberg LK, Raber J \& Scott JD 2008 Loss of AKAP150 perturbs distinct neuronal processes in mice. PNAS 105 12557-12562.

Uhler MD, Carmichael DF, Lee DC, Chrivia JC, Krebs EG \& McKnight GS $1986 a$ Isolation of cDNA clones coding for the catalytic subunit of mouse cAMP-dependent protein kinase. PNAS 83 1300-1304.

Uhler MD, Chrivia JC \& McKnight GS $1986 b$ Evidence for a second isoform of the catalytic subunit of cAMPdependent protein kinase. Journal of Biological Chemistry 261 15360-15363.

Vallar L, Spada A \& Giannattasio G 1987 Altered Gs and adenylate cyclase activity in human GH-secreting pituitary adenomas. Nature 330 566-568.

Vanfleteren JR \& De Vreese A 1997 Modulation of kinase activities in dauers and in long-lived mutants of Caenorhabditis elegans. Journals of Gerontology. Series A, Biological Sciences and Medical Sciences 52 B212-B216.

Vatner DE, Asai K, Iwase M, Ishikawa Y, Wagner TE, Shannon RP, Homcy CJ \& Vatner SF 1998 Overexpression of myocardial Gsalpha prevents full expression of catecholamine desensitization despite increased beta-adrenergic receptor kinase. Journal of Clinical Investigation 101 1916-1922.

Veugelers M, Wilkes D, Burton K, McDermott DA, Song Y, Goldstein MM, La Perle K, Vaughan CJ, O'Hagan A, Bennett KR et al. 2004 Comparative PRKAR1A genotype-phenotype analyses in humans with Carney complex and prkarla haploinsufficient mice. PNAS 101 14222-14227.
Vijayaraghavan S, Goueli SA, Davey MP \& Carr DW 1997 Protein kinase A-anchoring inhibitor peptides arrest mammalian sperm motility. Journal of Biological Chemistry 272 4747-4752.

Walsh DA, Perkins JP \& Krebs EG 1968 An adenosine $3^{\prime}, 5^{\prime}$-monophosphate-dependant protein kinase from rabbit skeletal muscle. Journal of Biological Chemistry 243 3763-3765.

Weinstein LS, Shenker A, Gejman PV, Merino MJ, Friedman E \& Spiegel AM 1991 Activating mutations of the stimulatory $\mathrm{G}$ protein in the McCune-Albright syndrome. New England Journal of Medicine 325 1688-1695.

Weinstein LS, Yu S, Warner DR \& Liu J 2001 Endocrine manifestations of stimulatory $\mathrm{G}$ protein alpha-subunit mutations and the role of genomic imprinting. Endocrine Reviews 22 675-705.

Woodford TA, Correll LA, McKnight GS \& Corbin JD 1989 Expression and characterization of mutant forms of the type I regulatory subunit of cAMP-dependent protein kinase. The effect of defective cAMP binding on holoenzyme activation. Journal of Biological Chemistry 264 13321-13328.

Yamasaki H, Mizusawa N, Nagahiro S, Yamada S, Sano T, Itakura M \& Yoshimoto K 2003 GH-secreting pituitary adenomas infrequently contain inactivating mutations of PRKAR1A and LOH of 17q23-24. Clinical Endocrinology 58 464-470.

Yang Y, Mahaffey CL, Berube N \& Frankel WN 2006 Interaction between fidgetin and protein kinase A-anchoring protein AKAP95 is critical for palatogenesis in the mouse. Journal of Biological Chemistry 281 22352-22359.

Yin Z, Jones GN, Towns WH II, Zhang X, Abel ED, Binkley PF, Jarjoura D \& Kirschner LS $2008 a$ Heart-specific ablation of Prkarla causes failure of heart development and myxomagenesis. Circulation 117 1414-1422.

Yin Z, Williams-Simons L, Parlow AF, Asa S \& Kirschner LS 2008b Pituitary-specific knockout of the Carney complex gene Prkar1a leads to pituitary tumorigenesis. Molecular Endocrinology 22 380-387.

Yin Z, Williams-Simons L, Rawahneh L, Asa S \& Kirschner LS 2008c Development of a pituitary-specific cre line targeted to the Pit-1 lineage. Genesis 46 37-42.

Yonemoto W, McGlone ML \& Taylor SS 1993 $N$-myristylation of the catalytic subunit of cAMPdependent protein kinase conveys structural stability. Journal of Biological Chemistry 268 2348-2352.

Zeiger MA, Saji M, Gusev Y, Westra WH, Takiyama Y, Dooley WC, Kohn LD \& Levine MA 1997 Thyroidspecific expression of cholera toxin A1 subunit causes thyroid hyperplasia and hyperthyroidism in transgenic mice. Endocrinology 138 3133-3140.

Zhu W \& Saba S 2003 Cardiac electrophysiologic abnormalities in the CREBA133 transgenic mouse model of idiopathic dilated cardiomyopathy. Journal of Cardiovascular Electrophysiology 14 982-989. 